DOI: $10.4274 / m j i m a .2018 .35$

Mediterr J Infect Microb Antimicrob 2018;7:35

Erişim: http://dx.doi.org/10.4274/mjima.2018.35

\title{
Antibiotic Consumption, Resistance Data, and Prevention Strategies
}

Antibiyotik Tüketimi, Direnç Verileri ve Önlem Stratejileri

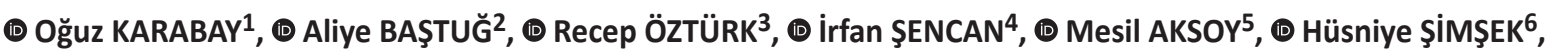

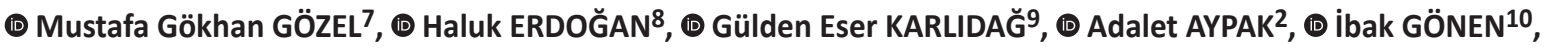

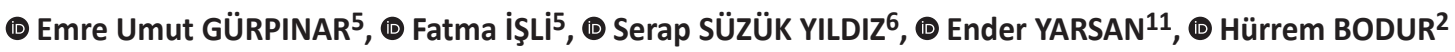

1Sakarya University Faculty of Medicine, Department of Infectious Diseases and Clinical Microbiology, Sakarya, Turkey

2 University of Health Sciences, Ankara Numune Health Training and Research Center, Clinic of Infectious Diseases and Clinical Microbiology,

Ankara, Turkey

${ }^{3}$ Medipol University Faculty of Medicine, Department of Infectious Diseases and Clinical Microbiology, istanbul, Turkey

4 University of Health Sciences, Dışkapı Yıldırım Beyazıt Health Application and Research Center, Clinic of Infectious Diseases and Clinical Microbiology, Ankara, Turkey

5 Turkish Medicines and Medical Devices Agency, Rational Drug Use Unit, Ankara, Turkey

${ }^{6}$ Ministry of Health Directorate General of Public Health, Department of Microbiology Reference Laboratories and National Antimicrobial

Resistance Surveillance Laboratory, Ankara, Turkey

${ }^{7}$ Ankara Ministry of Health Directorate General of Public Health, Department of Microbiology Reference Laboratories, Ankara, Turkey

${ }^{8}$ Başkent University Faculty of Medicine, Department of Infectious Diseases and Clinical Microbiology, Alanya, Turkey

${ }^{9}$ Elazığ Training and Research Hospital, Clinic of Infectious Diseases and Clinical Microbiology, Elazı̆̆, Turkey

10 Special Silivri Medical Park Hospital, Clinic of Infectious Diseases and Clinical Microbiology, İstanbul, Turkey

${ }^{11}$ Ankara University Faculty of Veterinary Medicine, Department of Pharmacology and Toxicology, Ankara, Turkey

\section{Abstract}

Data related to increasing antibiotic consumption in the world and in Turkey are alarming. This over-consumption is also triggering antibiotic resistance. Unfortunately, Turkey is one of the countries where antibiotic resistance is quite high. Serious efforts have been made in recent years to overcome these problems. However, there are still many distances to be taken. Today, evaluation of antibiotic consumption and consumption in hospitals is determined by antibiotic stewardship. In this report, it is aimed to summarize main items of antibiotic stewardship, global antibiotic consumption and Turkey-wide status, resistance data, evaluation of strategies to prevent resistance, and measures to be taken.

Keywords: Antibiotic resistance in the future, antimicrobial stewardship, colistin resistant Acinetobacter baumannii, extended-spectrum betalactamases, carbapenem-resistant Enterobacteriaceae

Öz

Dünyada ve ülkemizde antibiyotik tüketiminin artışına ilişkin veriler alarm vermektedir. Aşırı tüketim artan antibiyotik direncini tetiklemektedir. Ne yazık ki Türkiye antibiyotik direncinin en yüksek olduğu ülkelerdendir. Bu sorunları yenmek için son yıllarda ciddi çabalar verilse de halen alınması gereken çok yol vardır. Bugün hastanelerde antibiyotik tüketimi, tüketimin değerlendirilmesi ve strateji geliştirilmesi için antibiyotik yönetişimi kullanılmaktadır. Bu raporda, antibiyotik yönetişiminin başııca bileşenleri, antibiyotik tüketiminin global ve ülkemiz genelindeki durumu, direnç verileri, direnci engellemeye yönelik stratejilerin değerlendirilmesi ve alınması gereken önlemlerin güncel veriler eşliğinde ortaya konulması amaçlanmıştır.

Anahtar Kelimeler: Gelecekte antibiyotik direnci, antimikrobiyal yönetişim, kolistin dirençli Acienetobacter baumannii, genişlemiş spektrumlu beta-laktamazlar, karbapenem-dirençli Enterobacteriaceae

Cite this article as: Karabay 0 , Baştuğ A, Öztürk R, Şencan İ, Aksoy M, Şimşek H, Gözel MG, Erdoğan H, Karlıdağ GE, Aypak A, Gönen İ, Gürpınar EU, İşli F, Süzük Yıldız S, Yarsan E, Bodur H. Antibiotic Consumption, Resistance Data, and Prevention Strategies. Mediterr J Infect Microb Antimicrob. $2018 ; 7: 35$. 


\section{Introduction}

The aim of this report is to review all aspects of antimicrobial resistance (AMR), which seriously threatens the successes brought about by modern medicine, to present the available national and global data, and to contribute to antimicrobial stewardship programs (ASP) based on current information. The report includes contributions written by specialists in various Turkish centers, under the coordination of the Infectious Diseases and Clinical Microbiology Specialty Society of Turkey (EKMUD).

\section{The Current State of Global Antimicrobial} Resistance

Antibacterial resistance is a common and life-threatening problem that develop in infectious bacteria in hospitals and the community. Currently antibiotic resistance makes the treatment of these infections increasingly difficult and sometimes even impossible ${ }^{[1]}$.

Resistance to each new antibacterial drug develops eventually. The development of resistance in microorganisms is a normal evolutionary process. However, the widespread use of antibacterial drugs considerably accelerates the emergence of resistance ${ }^{[1-3]}$.

Antimicrobials, especially antibiotics, are the keystones of modern medicine. With the introduction of penicillins, mortality due to pneumococcal pneumonia was reduced from $20-40 \%$ to about $5 \%$ and mortality due to pneumococcal bacteremia from 50$80 \%$ to about $18-20 \%$. Although common community-acquired infections such as bacterial pneumonia were easily treated with penicillins, current guidelines specify that they should only be used in patients without risk factors associated with resistant pathogens. Cystitis, one of the most common infections in women, could be treated easily with oral drugs in the past, whereas parenteral drugs are widely needed today. The antibacterial drugs currently used to prevent surgical site infections may be less effective and sometimes even ineffective. Infections that are common in neonatal and intensive care units have become extremely difficult and sometimes even impossible to treat ${ }^{[1]}$.

The World Health Organization (WHO) issued its first global report on the surveillance of antibacterial resistance in 2014 and published data on resistance to antibacterial drugs commonly used for the treatment of infections caused by globally important bacteria. This report presents data on the resistance and decreased susceptibility of Escherichia coli, Klebsiella pneumoniae, Staphylococcus aureus, Streptococcus pneumoniae, non-typhoidal Salmonella, Shigella spp., and Neisseria gonorrhoeae to common antibiotics based on national surveillance data and studies conducted in countries in the six
WHO regions. These data are summarized in Tables 1, 2, and 3. Since these microorganisms are among the most common agents of hospital and community-acquired infections, the identified resistance profiles have important public health implications ${ }^{[2]}$.

Escherichia coli, a member of the normal intestinal flora in human and animals, is one of main causative agents of community- and hospital-acquired urinary tract infections, bloodstream infections in all age groups, neonatal meningitis, and food-borne infections. While some studies reported very low quinolone resistance rates (0-8\%) in the America, European, and Western Pacific regions, there are also studies from the five WHO regions other than Europe reporting quinolone resistance rates over 50\%. Similarly, there are studies reporting over 50\% resistance to third-generation cephalosporins in all six WHO regions (Table 1). Resistance to third-generation cephalosporins means that the use of broader-spectrum, last-choice options like carbapenem is required. This leads to higher treatment costs and increased rates of carbapenem resistance ${ }^{[3]}$.

Like E. coli, bacteria of the genus Klebsiella are also commonly found in the normal human gut flora. However, K. pneumoniae infections are more common in hospitals, preterm and low birth weight infants, individuals with immunosuppression, diabetes mellitus, chronic alcohol use, and those receiving advanced medical support in intensive care units ${ }^{[3,4]}$. Thirdgeneration cephalosporin resistance is higher in $K$. pneumoniae strains than in $E$. coli, with resistance rates over $50 \%$ reported in all WHO regions. More importantly, carbapenem resistance in $K$. pneumoniae has been reported from all WHO regions. Resistance rates over 50\% have been reported in two regions (Eastern Mediterranean and Europe) (Table 1). Tigecycline and colistin, which are used as the last resorts in the treatment of carbapenem-resistant infections, have clinical limitations and are not widely available in all parts of the world ${ }^{[3-6]}$. Furthermore, resistance to tigecycline and colistin has also been reported in these strains, suggests that the current problem is progressing toward complete insolubility ${ }^{[3-7]}$.

Staphylococcus aureus is a part of the skin and nose mucosa flora. However, it is also one of the most important infectious agents in humans. It causes skin, soft tissue, bone, joint, and bloodstream infections, and is the most common cause of postoperative skin and soft tissue infections ${ }^{[8,9]}$. Methicillinresistant S. aureus (MRSA) rates over 20\% have been reported in all WHO regions, and studies with MRSA rates of $>80 \%$ are included in the WHO Antimicrobial Resistance Report (Table 2) ${ }^{[2]}$. Antibiotics used to treat MRSA infections, such as vancomycin and teicoplanin, are only used parenterally. They are more expensive, and require close monitoring due to serious potential side effects. The rise in MRSA infections necessitates the prophylactic use of these drugs prior to surgical procedures. This approach increases costs and side effects ${ }^{[10]}$. 
Streptococcus pneumoniae is one of the leading causes of otitits media, bacterial meningitis, and community-acquired pneumonia that may be fatal in children under the age of five ${ }^{[11]}$. Penicillin non-susceptibility in pneumococcus strains has been reported from all WHO regions and rates exceeding 50\% have been reported in some regions (Table 2). The WHO Antimicrobial Resistance Report highlights significant shortcomings in surveillance practices for monitoring resistance in S. pneumoniae and mentions the insufficiency of data coming from three WHO regions in particular (Africa, Eastern Mediterranean, and SouthEast Asia).

Bacteria of the genus Salmonella are one of the main causes of foodborne infections worldwide ${ }^{[12]}$. Non-typhoidal Salmonella strains are the main pathogen of food-borne gastrointestinal system infections and have shown a significant increase in recent years. The increase in incidence is reported primarily in the South-East Asia and Western Pacific regions. However no study has investigated the prevalence of non-typhoidal Salmonella in Turkey. According to national data, the rate of quinolone resistance in non-typhoidal Salmonella is generally below 5\%, while rates of 35\% and $49 \%$ have been reported in the Africa and Eastern Mediterranean regions and 96\% in one region of the America (Table 3). Resistant Salmonella strains are associated with higher frequency of invasive disease, hospitalization, and mortality ${ }^{[10]}$.

Shigella species are one of the major causes of diarrhea. It is an important public health problem for children aged $<5$-year-old in low-income, crowded communities where basic needs such as sanitation services and clean water supply cannot be met. The WHO Antimicrobial Resistance Report states that resistance

Table 1. Resistance rates in Escherichia coli and Klebsiella pneumoniae

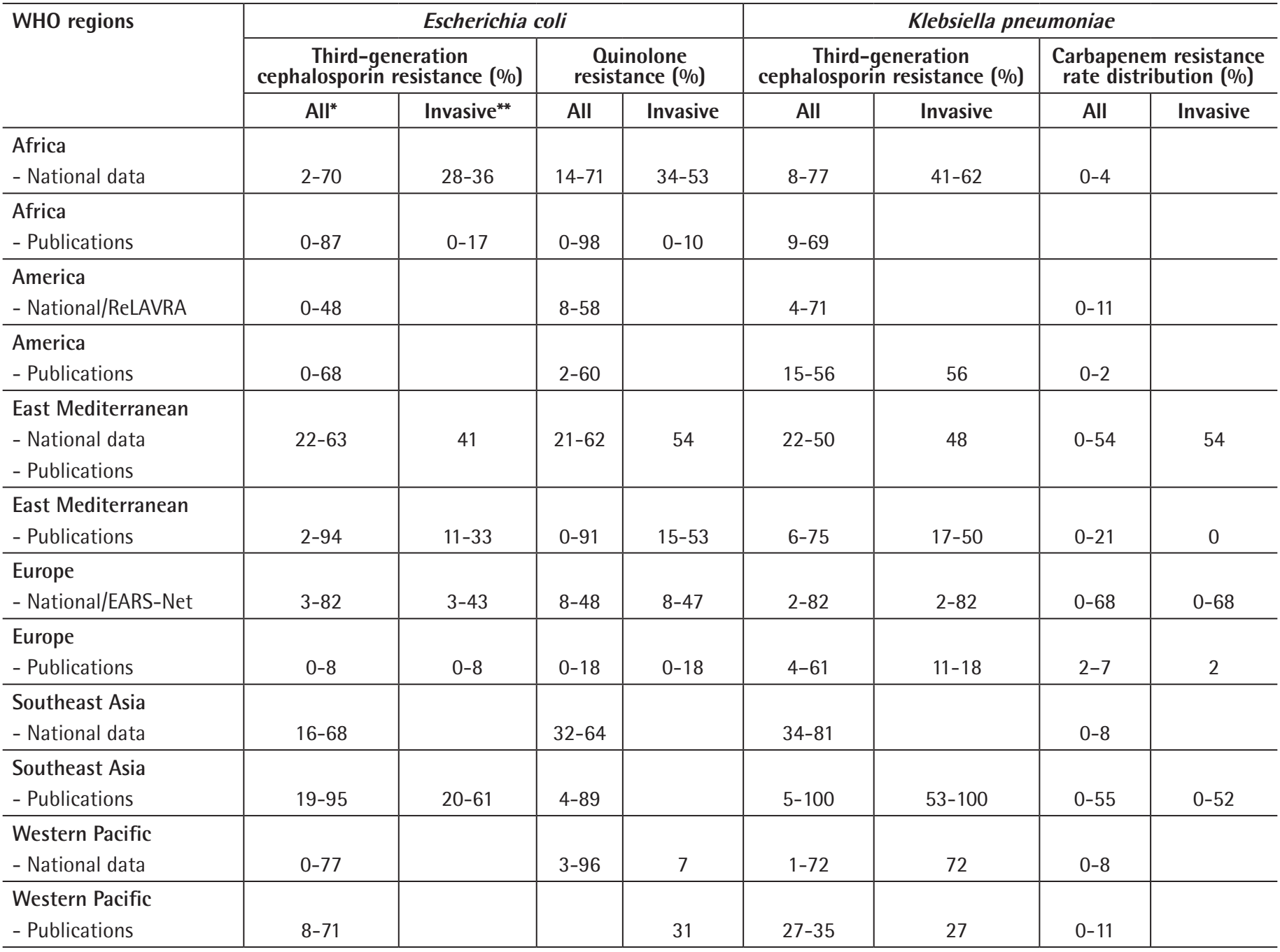

*All strains

**Invasive isolates including pathogens causing bloodstream infections and meningitis.

ReLAVRA: Latin American Antimicrobial Resistance Surveillance Network, EARS-Net: European Antimicrobial Resistance Surveillance Network.

(National surveillance and antibiotic resistance data of World Health Organization regions) 
rates are generally below 10\% (Table 3), but data at the national level come from a small number of countries. More data are needed to close the gap regarding this issue ${ }^{[12]}$.

Neisseria gonorrhoeae was completely susceptible to penicillins in the 1970s but developed high levels of resistance to penicillin and tetracycline in the 1980s (resistance rates reaching $86 \%$ and $85 \%$, respectively) and to quinolones in the 2000s (resistance rates reaching 35\%). As a result, the use of third-generation cephalosporins such as ceftriaxone is being widely used, and currently emerging resistance is severely limiting treatment options (Table 3).

Infections in neonatal care facilities are important due to the high mortality rate. Data from developing countries indicate significant levels of resistance to WHO-recommended options for neonatal infections (ampicillin and gentamicin). Gentamicin resistance has been detected in 70\% of Klebsiella spp. and 50\% of $E$. coli strains. In addition, ampicillin resistance has been detected in $60-70 \%$ of E. coli and almost 100\% of Klebsiella spp. ${ }^{[12,13]}$.

In a report regarding AMR data in major bacterial agents of healthcare-associated infections, the US Centers for Disease Control and Prevention (CDC) resistance reported resistance rates of $0-27.9 \%$ for carbapenem-resistant Enterobacteriaceae, 32.5-67.8\% for MRSA, 3.1-46.9\% for multidrug resistant (MDR) Pseudomonas aeruginosa, and 5.0-88.1\% for MDR Acinetobacter. Rates of vancomycin resistance were reported as 38.5-86.5\% in Enterococcus faecium and 0-17.8\% in Enterococcus faecalis ${ }^{[12,13]}$. The 2016 European Centre for Disease Prevention and Control (ECDC) AMR surveillance report including data from European Union/European Economic Area (EU/EEA) countries stated

Table 2. Resistance rates in Staphylococcus aureus and Streptococcus pneumoniae

\begin{tabular}{|c|c|c|c|c|}
\hline \multirow[t]{3}{*}{ WHO regions } & \multirow{2}{*}{\multicolumn{2}{|c|}{ Staphylococcus aureus }} & \multicolumn{2}{|c|}{ Streptococcus pneumoniae } \\
\hline & & & Penicillin resistance $(\mathrm{R})$, & on-susceptibility (NS) rate (\%) \\
\hline & All & Invasive & All & Invasive \\
\hline $\begin{array}{l}\text { Africa } \\
\text { - National data }\end{array}$ & $12-80$ & 52 & 3-16 (R), 57-60 (NS) & $3(\mathrm{R})$ \\
\hline $\begin{array}{l}\text { Africa } \\
\text { - Publications }\end{array}$ & $0-100$ & $33-95$ & 1-100 (R), 9-69 (NS) & 9-18 (NS) \\
\hline $\begin{array}{l}\text { America } \\
\text { - National/ReLAVRA/SIREVA }\end{array}$ & $21-90$ & $43-45$ & $0-48^{b}$ & $0-48^{b}$ \\
\hline $\begin{array}{l}\text { America } \\
\text { - Publications }\end{array}$ & $2.4-90$ & & 53 (non-meningitis) (NS) & 64 (meningitis) (NS) \\
\hline $\begin{array}{l}\text { Eastern Mediterranean } \\
\text { - National data }\end{array}$ & $10-53$ & 53 & 13-34 (R), 5 (NS) & $34(\mathrm{R})$ \\
\hline $\begin{array}{l}\text { Eastern Mediterranean } \\
\text { - Publications }\end{array}$ & $0-92$ & $13-18$ & $0.3-64(\mathrm{R}), 17-48(\mathrm{NS})$ & 2-14 (R), 17-40 (NS) \\
\hline $\begin{array}{l}\text { Europe } \\
\text { - National/EARS-Net }\end{array}$ & $0.3-60$ & $0.3-6$ & 0-61 (R), 0.9-73 (NS) & $0.9-61(N S), 32-45^{b}$ \\
\hline $\begin{array}{l}\text { Europe } \\
\text { - Publications }\end{array}$ & $27-80$ & $27-50$ & $13-68$ (NS) & 13 (NS) \\
\hline $\begin{array}{l}\text { Southeast Asia } \\
\text { - National data } \\
\text { - Publications }\end{array}$ & $10-26$ & 37 & $47-48^{b}$ & $0(\mathrm{R})$ \\
\hline $\begin{array}{l}\text { South-East Asia } \\
\text { - Publications }\end{array}$ & $2-81$ & 37 & $0-6(R)$ & $0(\mathrm{R})$ \\
\hline $\begin{array}{l}\text { Western Pacific } \\
\text { - National data }\end{array}$ & $4-84$ & & $17-64$ (NS), 0-47b & \\
\hline $\begin{array}{l}\text { Western Pacific } \\
\text { - Publications }\end{array}$ & 60 & & 44-96 (R), 0-69 (NS) & 44 (R), 0 (NS) \\
\hline
\end{tabular}

${ }^{*}$ All strains

**Invasive isolates include bloodstream infections and meningitis

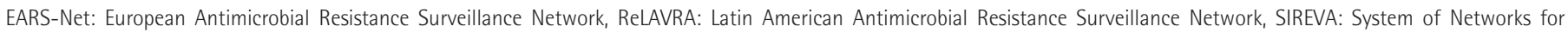
Surveillance of the Bacterial Agents Responsible for Pneumonia and Meningitis, MRSA: Methicillin-resistant Staphylococcus aureus 
that $55.4 \%$ of Acinetobacterspp. isolates were resistant to at least one group of antibiotics (quinolones, aminoglycosides, or carbapenems) and that $33.9 \%$ of $P$. aeruginosa strains were resistant to at least one group of antibiotics (piperacillintazobactam, quinolones, ceftazidime, aminoglycosides, or carbapenems). Furthermore, the report confirmed that MRSA remains as an important pathogen and reported more prevalent vancomycin-resistant E. faecium rates and higher macrolide resistance than penicillin resistance in $S$. pneumoniae in many countries ${ }^{[1]}$.

The high rate of extended-spectrum beta-lactamase (ESBL) production in E. coli and K. pneumoniae limits the use of broad-spectrum cephalosporins and necessitates the use of carbapenem as first-line therapy in patients with confirmed or suspected sepsis, particularly in neonatal or intensive care units. However, the intensive use of antibiotics (especially carbapenem) in these facilities leads to the emergence of carbapenem-resistant Enterobacteriaceae and Acinetobacter spp. infections that are pan resistant with few or no treatment options. The development of resistance against carbapenems, which were the most effective treatment options for MDR strains until recently, has made Gram-negative microorganisms probably the most important global threat ${ }^{[6,14]}$.

In summary, medical practices such as organ transplantations, cancer chemotherapies, and advanced intensive care support have become more common due to modern medical advances. These also result in more common development of both community- and hospital-acquired infections. Infections

Table 3. Resistance rates in non-typhoidal Salmonella, Shigella, and Neisseria gonorrhoeae

\begin{tabular}{|c|c|c|c|c|}
\hline \multirow{3}{*}{ WHO regions } & \multirow{2}{*}{\multicolumn{2}{|c|}{$\begin{array}{c}\text { Non-typhoidal Salmonella } \\
\text { Quinolone resistance rates } \\
(\%)\end{array}$}} & \multirow{3}{*}{$\begin{array}{c}\text { Shigella species } \\
\begin{array}{c}\text { Quinolone resistance } \\
\text { rates (\%) }\end{array} \\
\text { All }\end{array}$} & \multirow{3}{*}{$\begin{array}{c}\text { Neisseria gonorrhoeae } \\
\begin{array}{c}\text { Third-generation cephalosporin } \\
\text { resistant rate distribution (\%) }\end{array} \\
\text { All }\end{array}$} \\
\hline & & & & \\
\hline & All & Invasive & & \\
\hline $\begin{array}{l}\text { Africa } \\
\text { - National data/GASP }\end{array}$ & $0-35$ & & $0-3$ & $0-12$ \\
\hline $\begin{array}{l}\text { Africa } \\
\text { - Publications }\end{array}$ & $0-30$ & $0-30$ & $0-9$ & 0 \\
\hline $\begin{array}{l}\text { America } \\
\text { - National data/GASP/GISP }\end{array}$ & $0-96$ & & $0-8$ & $0-31$ \\
\hline $\begin{array}{l}\text { America } \\
\text { - Publications }\end{array}$ & 0 & & $0-20$ & \\
\hline $\begin{array}{l}\text { Eastern Mediterranean } \\
\text { - National data/GASP } \\
\text { - Publications }\end{array}$ & $2-49$ & 6 & $3-10$ & $0-12$ \\
\hline $\begin{array}{l}\text { Eastern Mediterranean } \\
\text { - Publications }\end{array}$ & $0-46$ & & $0-41.3$ & 0 \\
\hline $\begin{array}{l}\text { Europe } \\
\text { - National/FWD-Net/EURO-GASP/GRASP } \\
\text { - Publications }\end{array}$ & $\begin{array}{c}2-3 \\
13\end{array}$ & & $\begin{array}{c}0-47 \\
0\end{array}$ & $\begin{array}{c}0-36 \\
0\end{array}$ \\
\hline $\begin{array}{l}\text { Europe } \\
\text { - Publications }\end{array}$ & 13 & & 0 & 0 \\
\hline $\begin{array}{l}\text { South-East Asia } \\
\text { - National data/GASP }\end{array}$ & $0.2-4$ & & & \\
\hline $\begin{array}{l}\text { South-East Asia } \\
\text { - Publications }\end{array}$ & 1.4 & & $0-82$ & $0-5$ \\
\hline $\begin{array}{l}\text { Western Pacific } \\
\text { - National data/GASP }\end{array}$ & $0-14$ & & $3-28$ & $0-31$ \\
\hline $\begin{array}{l}\text { Western Pacific } \\
\text { - Publications }\end{array}$ & $0-0.3$ & & 2 & \\
\hline
\end{tabular}

*All strains

**Invasive isolates include bloodstream infections and meningitis. National surveillance and antibiotic resistance data of World Health Organization regions

GASP: Gonococcal Antimicrobial Surveillance Programme, GISP: Gonococcal Isolate Surveillance Project, FWD-Net: Food- and Waterborne Diseases and Zoonoses Network, Euro-GASP:

European Gonococcal Antimicrobial Surveillance Programme, GRASP: Gonococcal Resistance to Antimicrobials Surveillance Programme 
caused by MDR microorganisms may lead to extended hospital stays, loss of labor productivity, increased costs, and even death. As we continue to face serious problems in the development of novel antibiotics, AMR surveillance should be practiced at every stage of healthcare, and available antibiotics should be used in accordance with practices of antimicrobial stewardship. From a microbiological perspective, it is an indisputable fact that the development of resistance is an inevitable process. Large-scale health policies to prevent the emergence and spread of resistance are necessary to maintain the effectiveness of modern medical practices that are currently available or in development.

\section{The Current State of Antibiotic Resistance in} Major Pathogens in Turkey

As international travel has become more common due to tourism, migration, and trade, the problem of AMR has reached a global scale that involves the entire world. Individual countries should establish antibiotic use policies and AMR control mechanisms based on local data and global approaches proposed by WHO. For this reason, national AMR and antibiotic consumption surveillance studies are of great importance ${ }^{[15]}$.

In Turkey, the National Antimicrobial Resistance Surveillance System (NARSS) was established in 2011 with the coordination of the Turkish Public Health Institution (TPHI) to collect reliable national AMR data. NARSS initially included 77 participating centers from a total of 45 provinces, which increased to a total of 120 centers from 57 provinces as the project expanded in scope in 2015 and 2017. Infectious strains of $E$. coli, K. pneumoniae, P. aeruginosa, S. aureus, S. pneumoniae, E. faecium/faecalis, and Acinetobacter spp. isolated from clinical blood and cerebrospinal fluid samples and the antibiotic susceptibility test results for these strains are monitored in the surveillance program.
Antibiotic susceptibility testing is performed by participating laboratories using the disk diffusion, automated system, and/or gradient strip test methods. The data are analyzed using the WHONET software provided by the WHO. During this analysis, the first isolate of each patient is included and repeated records per patient are excluded ${ }^{[16-18]}$.

As of November 2013, NARSS has been included in the Central Asian and Eastern European Antimicrobial Resistance Surveillance (CAESAR) network run by the WHO European Office. The methodology employed in the NARSS is fully compatible with the European Antimicrobial Resistance Surveillance Network (EARSS-Net) and CAESAR network methodology. This allows comparison of AMR data from Turkey with international data. In CAESAR reports, data from Turkey are published in the "Level A" category, which means they are appropriate in their representation of the target population, adequate assessment of national AMR patterns, and reliability.

\section{NARSS-CAESAR Results}

A total of 16,494 isolates from Turkey were included in the analysis in 2016, of which 24\% were E. coli, 18\% K. pneumoniae, 15\% Acinetobacterspp., 15\% S. aureus, 19\% E. faecalis and E. faecium, and 1\% S. pneumoniae. The results are summarized in Tables 1-8 ${ }^{[19]}$. Extended-spectrum betalactamase production was detected in $47.8 \%$ of $E$. coli isolates and $58 \%$ of $K$. pneumoniae isolates. Turkish national data shows high resistance to third-generation cephalosporins and fluoroquinolones in invasive $E$. coli and $K$. pneumoniae isolates. In particular, the increased carbapenem resistance in $K$. pneumoniae isolates and high resistance rates among Acinetobacter isolates are worrying. When compared with the 2016 EARSS-Net results, resistance rates in Turkey are well above EU averages but are similar to those of other Mediterranean countries ${ }^{[20]}$.

Table 4. Antibiotic resistance rates in invasive Escherichia coli and Klebsiella pneumoniae isolates (2016)

\begin{tabular}{|c|c|c|c|c|}
\hline \multirow[t]{2}{*}{ Antibiotics* } & \multicolumn{2}{|c|}{ Escherichia coli } & \multicolumn{2}{|c|}{ Klebsiella pneumoniae } \\
\hline & $\mathbf{n}$ & Resistance (\%) & $\mathbf{n}$ & Resistance (\%) \\
\hline Aminopenicillins & 2887 & 79 & - & - \\
\hline Piperacillin-tazobactam & 3333 & 23 & 2460 & 59 \\
\hline Third-generation cephalosporins & 3546 & 51 & 2589 & 68 \\
\hline Ceftazidime & 3349 & 44 & 2568 & 71 \\
\hline Carbapenems & 3865 & 3 & 2837 & $18 \%$ \\
\hline Aminoglycosides & 3679 & 27 & 2712 & 48 \\
\hline Amikacin & 3781 & 1 & 2820 & 22 \\
\hline Fluoroquinolones & 3670 & 50 & 2770 & 55 \\
\hline Multidrug resistance & 3111 & 18 & 2361 & 35 \\
\hline
\end{tabular}


Table 5. Antibiotic resistance rates in invasive $P$. aeruginosa and Acinetobacter spp. isolates (2016)

\begin{tabular}{|c|c|c|c|c|}
\hline \multirow[t]{2}{*}{ Antibiotics** $^{* *}$} & \multicolumn{2}{|c|}{ Pseudomonas aeruginosa } & \multicolumn{2}{|c|}{ Acinetobacter spp. } \\
\hline & $n$ & Resistance (\%) & $\mathbf{n}$ & Resistance (\%) \\
\hline Piperacillin-tazobactam & 1203 & 31 & - & - \\
\hline Cefepime & 1168 & 30 & - & - \\
\hline Carbapenems & 1281 & 37 & 2373 & 92 \\
\hline Amikacin & 1285 & 13 & 2287 & 68 \\
\hline Fluoroquinolones & 1252 & 35 & 2324 & 92 \\
\hline Multidrug resistance & 1090 & 28 & 2266 & 76 \\
\hline
\end{tabular}

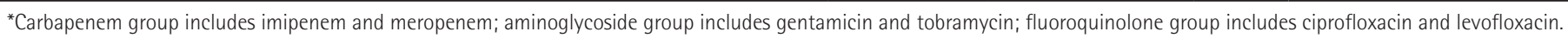

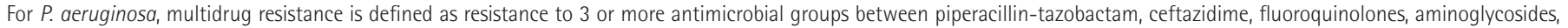

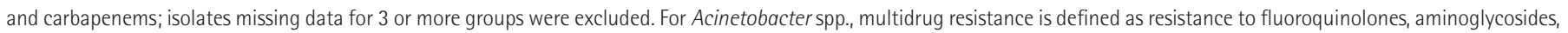
and carbapenems; isolates missing data for one or more groups were excluded

Table 6. Antibiotic resistance rates in invasive Staphylococcus aureus isolates (2016)

\begin{tabular}{|c|c|c|}
\hline \multirow[t]{2}{*}{ Antibiotics*** } & \multicolumn{2}{|c|}{$\begin{array}{c}\text { Staphylococcus } \\
\text { aureus }\end{array}$} \\
\hline & $\mathbf{n}$ & $\begin{array}{l}\text { Resistance } \\
\quad(\%)\end{array}$ \\
\hline Oxacillin & 1887 & 23 \\
\hline Fluoroquinolones & 2195 & 13 \\
\hline Vancomycin & 2465 & 0 \\
\hline Linezolid & 2360 & 0 \\
\hline
\end{tabular}

Table 7. Antibiotic resistance rates in invasive Streptococcus pneumoniae isolates (2016)

\begin{tabular}{l|c|c}
\hline Antibiotics*** & \multicolumn{2}{|c}{$\begin{array}{c}\text { Streptococcus } \\
\text { pneumoniae }\end{array}$} \\
\cline { 2 - 3 } & $\mathbf{n}$ & $\begin{array}{c}\text { Resistance } \\
(\%)\end{array}$ \\
\hline Penicillin (R) & 174 & 16 \\
\hline Penicillin (I+R) & 174 & 47 \\
\hline Third-generation cephalosporins (R) & 113 & 7 \\
\hline Third-generation cephalosporins (I+R) & 113 & 29 \\
\hline Fluoroquinolones (R) & 130 & 5 \\
\hline Macrolides (R) & 163 & 39 \\
\hline Multidrug resistance (I+R) & 155 & 30 \\
\hline $\begin{array}{l}\text { ****enicillin resistance was calculated according to nonmeningitis criteria } \\
\text { (meningitis criteria were used before 2016). Third-generation cephalosporin group }\end{array}$ \\
$\begin{array}{l}\text { includes cefotaxime and ceftriaxone; fluoroquinolone group includes levofloxacin } \\
\text { and moxifloxacin; macrolide group includes erythromycin, clarithromycin, and } \\
\text { azithromycin. Multidrug resistance is defined as resistance to penicillins and } \\
\text { macrolides; isolates missing data for one or more groups were excluded }\end{array}$
\end{tabular}

Table 8. Antibiotic resistance rates in invasive Enterococcus isolates (2016)

\begin{tabular}{l|c|c|c|c}
\hline \multirow{2}{*}{ Antibiotics } & \multicolumn{2}{|c|}{$\begin{array}{c}\text { Enterococcus } \\
\text { faecalis }\end{array}$} & \multicolumn{2}{c}{ Enterococcus faecium } \\
\cline { 2 - 5 } & $\mathbf{n}$ & $\begin{array}{c}\text { Resistance } \\
(\%)\end{array}$ & $\mathbf{n}$ & $\begin{array}{c}\text { Resistance } \\
(\%)\end{array}$ \\
\hline $\begin{array}{l}\text { Ampicillin/ } \\
\text { amoxicillin (I+R) }\end{array}$ & 1437 & 6 & 1392 & 91 \\
\hline $\begin{array}{l}\text { High-level } \\
\text { gentamicin (R) }\end{array}$ & 767 & 60 & 851 & 65 \\
\hline Vancomycin (R) & 1518 & 1 & 1467 & 15 \\
\hline Linezolid (I+R) & 1425 & 0 & 1368 & 1 \\
\hline
\end{tabular}

What Can We Expect in 25 Years If Antibiotic Resistance Continues to Increase at This Rate?

In recent years new AMR genes that confer resistance to all available antibiotics have been identified while bacteria that carry one or more AMR genes are rapidly spreading all over the world.

Many studies have been conducted to predict the impact of AMR on mortality and the global economic burden in order to gain a global understanding of the extent of this evolving problem. Jim $\mathrm{O}^{\prime} \mathrm{Neil}{ }^{[21]}$ reported that according to models based on published data such as ECDC reports, they estimate that 10 million people will die each year from 2050 onward and 300 million people will lose their lives within the next 35 years due to MDR infections if AMR cannot be maintained at the present level. It has also been reported that if the increase of AMR is not controlled and continues at the same rate, the gross national product will be $2-3.5 \%$ lower by the year 2050, and this will incur a global cost of 60-100 trillion dollars. The study reported that besides gross national product, other global issues such as the social effects and health expenses caused by AMR were not taken into 
account, and that if these parameters are also considered, the economic cost will have much greater implications in terms of how healthcare services are provided ${ }^{[3]}$. In addition to these consequences, secondary effects of AMR include increased risk of surgical site infections and development of infections in immunocompromised patients if antibiotics used in surgery or medical prophylaxis become ineffective.

Considered from another perspective, people may start avoiding travel to regions with a widespread AMR problem due to potential travel-related infections caused by resistant microorganisms. This should be a major cause for concern for all economies that depend on tourism, foreign direct investment, or global trade $\mathrm{e}^{[21]}$.

Globally, there are significant regional variations in AMR patterns patterns (Tables 1-3). This is partly attributable to differences in antibiotic consumption. AMR is a major problem that all countries, regardless of income level, should be concerned about and take precautions against.

It is important to assess what actions can be taken to accelerate vaccine trials and studies for the development of alternative therapies such as novel drugs and monoclonal antibodies and to reduce the spread of AMR. The WHO issued a Global Strategy Plan in 2001 aiming to prevent AMR, but due to a lack of progress they changed the policy and made a global call for "rational use of antibiotics" in 2005. Furthermore, by designating "antibiotic resistance" the theme of World Health Day 2011, the WHO highlighted the importance of this public health threat and invited all stakeholders to take responsibility in order to prevent the emergence and spread of AMR. In May 2015, a new global action plan including five main areas was established to combat antibiotic resistance ${ }^{[22]}$.

These objectives included:

1. Increasing awareness of the importance of AMR through effective communication channels,

2. AMR surveillance and planning educational programs aimed at strengthening our knowledge and evidence base,

3. Reducing the incidence of infection through effective sanitation, hygiene, and infection control measures,

4. Optimizing the use of antimicrobial drugs for human and animal health,

5. Creating funds for investments in new drugs, diagnostic tools, and vaccines based on the needs of all countries.

In conclusion, AMR is an urgent global crisis and it is imperative that all stakeholders fulfill their responsibilities to develop and comply with multisectoral national and international action plans.
National Policies and Practices in Turkey and Other Countries to Overcome Antibiotic Resistance

Interventions to minimize the development of AMR are difficult to implement. Excessive and inappropriate use of antimicrobials is the main cause of resistance. From 2000 to 2010, global antibiotic use increased by 36\%, 75\% of which stemmed from 5 rapidly growing countries (Brazil, Russia, China, India, and South Africa). There is a strong association between reduction of antibiotic use and community- and hospital-acquired infections. The prevalence of MRSA in the community can be reduced by $32 \%$ with community-level interventions, while hospital-level interventions can reduce the rate by $37 \%$. For example, a study conducted in Italy showed that antibiotic use in surgical prophylaxis decreased from 33\% to 24\% with the establishment of a hospital antibiotic control program ${ }^{[35]}$. Continuous training resulted in a reduction in antibiotic use for intra-abdominal infections as well as favorable changes in resistance patterns in a study conducted in China ${ }^{[23,37]}$.

\section{Public Interventions}

Public interventions play a key role in reducing AMR. Public intervention policies are generally the most cost-effective approach, having predefined minimum standards and widespread, homogeneous compliance. For example, with the introduction of the prescription evaluation project in Turkey, the number of antibiotic prescriptions decreased from 45,400,799 (34.94\% of all prescriptions) in 2011 to $38,177,660$ (33.99\%) in $2012^{[26]}$.

Public interventions targeting AMR involve parameters such as the formulation of guidelines, taxation, economic incentives, funding, regulations for professionals, and raising public awareness ${ }^{[2]}$. They include regulations on antimicrobial use to reduce antibiotic consumption as well as antibiotic policies, surveillance, management, infection control, and sanitation practices. Antibiotic stewardship requires the development of a top-down multidisciplinary awareness of antibiotic management in hospitals, from physicians to pharmacists and from patients to nurses, and the propagation of a shared responsibility regarding the prescription of antimicrobials under the leadership of infectious disease experts. Data collected through antibiotic stewardship should be incorporated with information technology systems that enable real-time interventions and complete technology integration should be achieved for data analysis. The WHO has also made a call on governments to take joint measures to reduce $\mathrm{AMR}^{[24]}$. Looking at the content of the surveillance program run by the ECDC, we see that the basic parameters are the existence of a national plan for combating AMR, the existence of strategic plans and 
practice guidelines for the appropriate use of antimicrobials in humans and animals, and AMR surveillance.

Restricting antibiotic prescriptions via regulations is another method that is implemented in several countries and generally yield positive results. In Italy, a restriction that allowed only the infectious diseases department to prescribe antibiotics in a large 2,500-bed hospital resulted in an 8.5\% decrease in antibiotic consumption according to daily defined dose (DDD)/1000 (DDD/1000 patient days) ${ }^{[25]}$. In Turkey, a reimbursement execution circular in February 2003 restricted the prescription of extended spectrum antibiotics to infectious diseases specialists. A comparison of total antibiotic consumption from the three years before and two years after this restriction, according to the standardized DDD/1000 formula and Intercontinental Marketing Services (IMS) data, revealed a slowing in the consumption increase and even an overall decrease in 2004 compared to $2003^{[25,26]}$.

In a meta-analysis of 48 studies (published between 2003 and 2013) that evaluate the change in the antibiotic resistance of $P$. aeruginosa strains in Turkey, rates of imipenem and meropenem resistance were determined as $29.4 \%$ and $32.1 \%$, respectively. Although there were marked changes in reports of antibiotic resistance by year (2003-2013), there were no statistically significant differences. The researchers interpreted these findings as evidence that policies for the rational and restricted use of antibiotics helped reduce resistance ${ }^{[27]}$.

A study conducted in Ankara monitored ESBL positivity rates in Enterobacteriaceae strains isolated from 12,535 urine cultures from outpatients treated between 2007-2013 and revealed a total ESBL positivity rate of $21.8 \%{ }^{[28]}$.

The issue of reducing AMR has been on the agenda of national decision-makers in Turkey for many years. Several programs have been created and various studies are being conducted to this end. The rational use of medicines, and by extension the rational use of antibiotics, is worded in the government program as "We will promote the rational use of medication and improve preventive healthcare", and the Turkish Ministry of Health (TMH) has been appointed to realize this goal.

The TMH Directorate General of Health Improvement (Sağlık Bakanlığı, Sağlığın Geliştirilmesi Genel Müdürlüğü) was appointed to "develop or oversee the development of programs of a cautionary, informative, and educational nature to protect and improve public health, prevent and reduce the risk of disease, and utilize diagnostic, therapeutic, and rehabilitative health services more efficiently". The strategic objectives and action plans of TMH Turkish Medicines and Medical Devices Agency (Türkiye Illaç ve Tıbbi Cihaz Kurumu-TMMDA), have included the rational use of drugs, and a performance indicator has been defined exclusively for the reduction of antibiotic consumption: Strategic objective 4: Ensuring the rational use of drugs by creating an informed physician, dentist, pharmacist, nurse, and consumer population; Action 4.1. The Rational Drug Use National Action Plan will be implemented. Performance indicator: Antibiotic use per 1000 persons based on Anatomical Therapeutic Chemical (ATC)/DDD methodology.

Furthermore, the Department of Infectious Diseases was established within the TPHI, a former TMH subsidiary. This department has been preserved in the process of the restructuring of the Turkish Directorate General of Public Health with the Legislative Decree No. 694 dated 25 August 2017. Its duties include the execution of activities aimed at monitoring and controlling AMR. Infection control committees established in hospitals have been assigned the task of "Controlling antibiotic use" by article 8 , section (b) of the Directive on Infection Control for Inpatient Treatment Institutions issued in 2005.

In summary, Turkey has shown decisiveness by addressing the issue of AMR and rational antibiotic use in governmental programs and through legislative regulations, appointing relevant units, and providing necessary resources. Hospital infection control committees are charged with implementation, the Directorate General of Health Promotion (DGHP) with raising community awareness. TMMDA and Directorate General of Public Health are responsible for the widespread education of healthcare personnel and surveillance of their medical practice. Although it is difficult to cite an exact starting date, periodic interventions carried out by relevant branch specialists and academicians and the surveillance, appropriate prophylaxis, and rational antibiotic use programs led by infection control committees in hospitals have been intensified since the year 2005. Building on this, the DGHP, TPHI, and TMMDA have held a 3-month intensive program about rational antibiotic use for upper respiratory tract infections (URTI) since the start of the year 2017. Based on its markedly positive results, the organizers are determined to expand and continue the program. This program and its outcome measures can be summarized as follows:

\section{Objective}

Reducing total antibiotic use by half with the rational use of antibiotics for URTI.

\section{Intervention}

Educating physicians: Educating physicians working in primary care; educating physicians working in secondary and tertiary care (ear nose throat, pediatrics, emergency).

Raising patient awareness: Posters and brochures in Family Health Centers (FHC), Community Health Centers, hospitals, public transportation, and informative videos. 
Raising public awareness: Public service announcements, media presence (TV, newspapers, agency, and social media).

\section{Program Outcomes}

Different studies have shown that implementation of the program was associated with a significant increase in awareness among the community and individuals presenting to healthcare centers regarding issues such as antibiotic resistance and the need to use antibiotics only when recommended by a doctor. Yağar and Soysa ${ }^{[29]}$ determined that the majority of physicians $(60.6 \%)$ had received education on the rational use of medicines in recent years. The authors emphasized that educational interventions regarding the rational use of medication in hospitals were at a satisfactory level. An evaluation of antibiotics dispensed to all outpatients nationwide showed that antibiotic sales had decreased by $20 \%$ during the time the program was implemented compared to the first week, and that this decrease was ongoing. Antibiotic sales from 2015 and 2016 were compared with those in 2017 to assess the effectiveness of the program, and it was observed that antibiotic sales in January-April 2017 decreased by 13.7\% compared to the same time period in 2015 and by $18.1 \%$ compared to 2016. In addition, due to previous reports that broad-spectrum antibiotics not recommended by guidelines (e.g., amoxicillin-beta-lactamase enzyme inhibitor combination or third-generation oral cephalosporins) were being used extensively for acute pharyngitis, the sales of antibiotics with the active ingredient cefdinir in the quarter in which the program was implemented were compared with those in the same periods of the previous two years. In the period of January-April 2017, when the program was implemented, there was a $29.7 \%$ decrease compared to 2015 and a $37.9 \%$ decrease compared to 2016. The total cost of the 3 million rapid beta (Streptococcus pyogenes) tests needed between 2017 and 2018 and the 300,000 rapid influenza A and B antigen identification tests provided in the year 2018 is about 5\% of the cost saved from antibiotics in only the first three months of 2017 due to the program.

There is no Turkish word to fully express the concept of "antimicrobial stewardship", which has been the topic of global discussion in recent years. The concepts of management (yönetim) and, antibiotic control (antibiyotik kontrolü) have been used previously in reference to the topic ${ }^{[30]}$. Although there is no word in our language that directly corresponds to "stewardship", we believe, based on what is intended and done within the scope of the concept, that governance (yönetişim) is a more appropriate equivalent, so as to also encompass the "careful and responsible management" aspect of the stewardship concept. Indeed, the Turkish Language Institution's "Güncel Türkçe Sözlük" (official dictionary of the Turkish) defines "yönetişim" as "the shared use of administrative, economic, and political authority in official and private organizations". Considered within the extensive framework at a national and institutional level, it can be recommended that "antimikrobiyal yönetişim" be used to convey "antimicrobial stewardship", which is a "process that enables the careful and responsible use of antimicrobial substances" as well as the "shared management" of this process at the national and institutional level. The broad framework of antimicrobial stewardship includes physicians, nurses, patients, institutional antimicrobial stewardship teams, hospital management, pharmaceutical manufacturers, veterinarians, farm owners, and the government, which defines and implements policy ${ }^{[31]}$.

According to evaluations perfromed in the US, the cost of antiinfective drugs has been reduced from US $\$ 590$ to US $\$ 21.38$ per 1000 patient days after the implementation of $\mathrm{ASP}^{[32]}$. It is estimated that $30 \%$ of outpatient antibiotic prescriptions are inappropriate ${ }^{[24]}$. Emergency departments are areas where patients can access health services very quickly ${ }^{[25]}$. It was determined in the US that 160 million people are admitted to emergency departments every year and $12.6 \%$ of them receive prescriptions for antibiotics. When antibacterial cultures and prescriptions were evaluated after emergency visits, approximately 50\% of the antibiotic prescriptions were corrected/adjusted ${ }^{[32]}$. In Turkey, the number of emergency department visits is about three times greater and the percentage of antibiotic prescriptions is several times higher ${ }^{[26,28,33]}$.

\section{Data on Antibiotic Consumption in Turkey}

In 2011, 53 member countries operating in affiliation with the WHO Regional Office for Europe adopted the "European Strategic Action Plan on Antibiotic Resistance" with the aim of halting the progression of antibiotic resistance in the region, improving antibiotic consumption and resistance surveillance systems, and increasing the international sharing of resistance data. The action plan has five main headings, one of which concerns ensuring the rational use of antimicrobial drugs and improving antimicrobial consumption surveillance. For this purpose, the member countries were charged with the development of surveillance systems that allow national and local monitoring of antimicrobial consumption in accordance with international standards. The antimicrobial surveillance system was intended to increase awareness of resistance among healthcare workers, monitor the results of the interventions, and evaluate the appropriateness of prescription practices.

Two antimicrobial consumption networks to provide this surveillance are currently in operation. The first of these is the European Surveillance of Antimicrobial Consumption Network (ESAC-Net), which is led by the ECDC and comprises EU and EEA member states. The second is the WHO-Antimicrobial Medicines Consumption (AMC) Network, which is led by WHO and run in affiliation with the WHO Regional Office for Europe but also includes non-EU member states. Since the establishment of the WHO-AMC network, the TMMDA has 
been calculating antimicrobial consumption data for Turkey and reporting them to the $\mathrm{WHO}$, enabling the validation of the data at international standards. Both of these European networks evaluate drug consumption using ATC/ DDD methodology, which is recommended by the WHO and allows international comparison of drug consumption data. The ATC classification system refers to the classification of drugs based on the organs or systems they affect and their chemical, pharmacological, and therapeutic properties. DDD is the assumed average daily maintenance dose in adults for the main indication of a drug in the ATC system. This allows the objective comparison between countries of pharmaceutical preparations with different doses, drugs with different pharmaceutical forms, and drug packages containing different amounts, as well as comparison of countries with different populations and box sale figures ${ }^{[34]}$. Data for Turkey were calculated using population information obtained from the Turkish Statistics Institute, box sales figures from IMS for 2012 and earlier, and sales figures from the Pharmaceutical Track and Trace System for 2013 and later. Data obtained from the Directorate General of Migration Management (under the Turkish Ministry of Interior) regarding the number of refugees under temporary protection in Turkey was used when calculating consumption for the given year. A series of calculations involving parameters such as the drug box sales figures for the target year, the population that year, and the package quantities, DDD, and strength value of the drug was performed to yield the DDD per 1000 inhabitants. These DDD values were used in comparisons between provinces and regions of Turkey and with other countries.

\section{Antibiotic Consumption in Turkey}

Antibiotic use in Turkey was first calculated using the ATC/DDD system and data from 2011 with the support of the University of Antwerp as part of the WHO-AMC studies. Turkey ranked first among 13 non-EU member European states with antibiotic consumption of 42.28 DDD. According to ESAC-Net data from the same year, Turkey also used more antibiotics than EU member states. The ESAC-Net data indicated that Greece had the highest consumption in Europe, with 37.7 DDD. The Netherlands had the lowest consumption at 11.4 DDD. This shows that based on DDD values, antibiotic consumption in Turkey was 4-fold greater than in the Netherlands ${ }^{[35]}$.

Retrospective calculations were later made to quantify consumption back to 2007. According to these results, total consumption was 35.07 DDD in 2007 and increased annually until 2011. Antibiotic consumption peaked in 2011 and then showed a decline to 40.18 DDD in 2016 (Figure 1) ${ }^{[36]}$.

When antibiotic consumption in Turkey is evaluated, betalactam antibiotics in the penicillin (J01C) group account for a large proportion of consumption. Drugs in this group comprised approximately $44 \%$ of total antibiotic consumption in all years analyzed. The second highest consumption was in the other beta-lactam antibiotics (J01D) group, followed by the macrolides, lincosamides, and streptogramins group (J01F) and quinolones (J01M) (Figure 1).

Although there were no marked changes in total consumption between 2007 and 2016, after 2012 there was a notable increase in the proportion of penicillins $(\mathrm{J} 01 \mathrm{C})$ and a decrease in the proportion of cephalosporins and quinolones in total consumption (Figures 1, 2). However, Turkey has the highest rate of quinolone and cephalosporin consumption among the WHO-

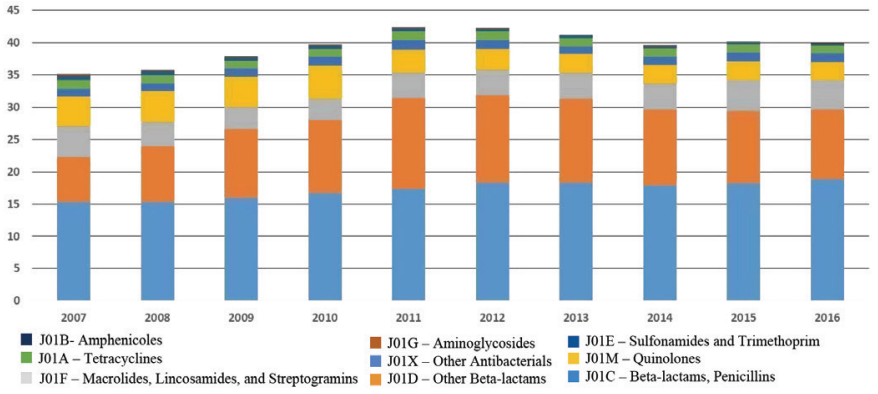

Figure 1. Antibiotic consumption rates in Turkey by year

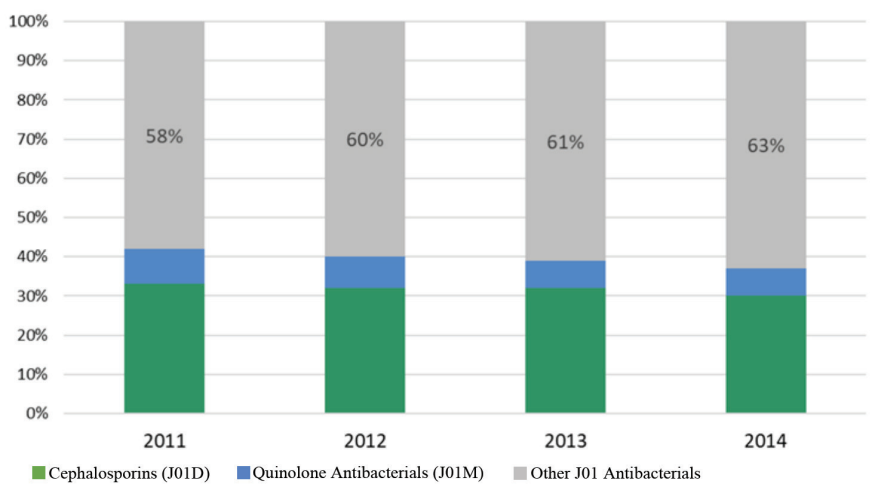

Figure 2. Rates of cephalosporin and quinolone usage relative to other antibiotics in Turkey between 2011-2014

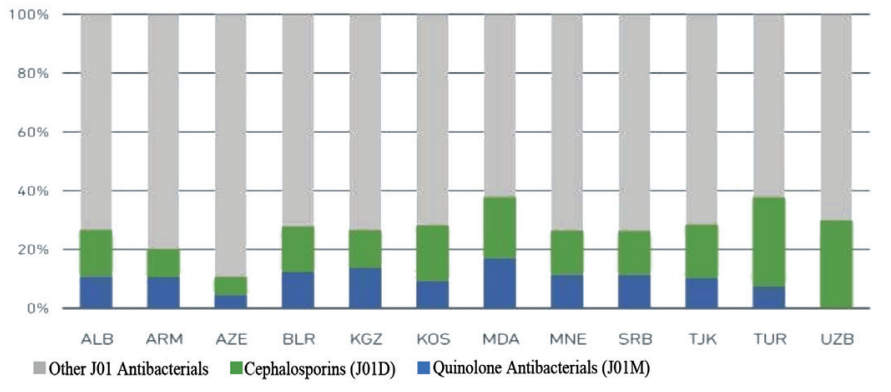

Figure 3. Rates of cephalosporin and quinolone usage relative to other antibiotics ${ }^{[37]}$

ALB: Albania, ARM: Armenia, AZE: Azerbaijan, BLR: Belarus, KGZ: Kyrgyzstan, KOS: Kosovo, MDA: Moldova, MNE: Montenegro, SRB: Serbia, TJK: Tajikistan, TUR: Turkey, UZB: Uzbekistan 
AMC Network member states (Figure 3).

Evaluation of cephalosporin use in WHO-AMC Network members reveals a striking difference between the consumption profile of Turkey and those of most other countries. First-generation cephalosporins are used less in Turkey than in other countries, while second-generation cephalosporins are used more (Figure 4).

A decrease in cephalosporin consumption has been recorded in Turkey every year between 2011 and 2014. While the proportion of second-generation cephalosporins in total cephalosporin consumption decreased, the proportion of third-generation cephalosporins increased (Figure 5).

Another important indicator used when evaluating antmicrobial consumption is the ratio of amoxicillin to the combination of amoxicillin/clavulanic acid. The preference of amoxicillin alone to amoxicillin/clavulanic acid is considered to be in accordance with the principles of rational antibiotic use ${ }^{[37]}$. In this regard, of all the WHO-AMC network member states, Turkey is the only country in which amoxicillin/ clavulanic acid consumption exceeds that of amoxicillin alone (Figure 6) ${ }^{[37]}$. Consumption of amoxicillin/clavulanic acid showed small but consistent increases relative to amoxicillin between 2011 and 2014 (Figure 7).

When we look at antibiotic use in Turkey in 2014 by

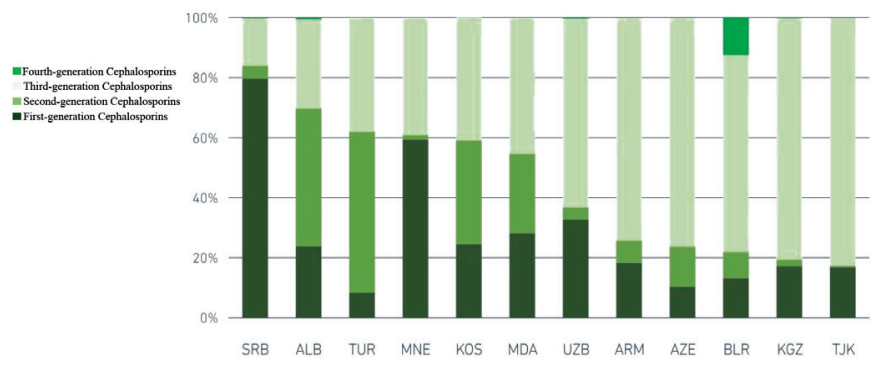

Figure 4. Usage rates of cephalosporins according to generation ${ }^{[37]}$ SRB: Serbia, ALB: Albania, TUR: Turkey, MNE: Montenegro, KOS: Kosovo, MDA: Moldova, UZB: Uzbekistan, ARM: Armenia, AZE: Azerbaijan, BLR: Belarus, KGZ: Kyrgyzstan, TJK: Tajikistan

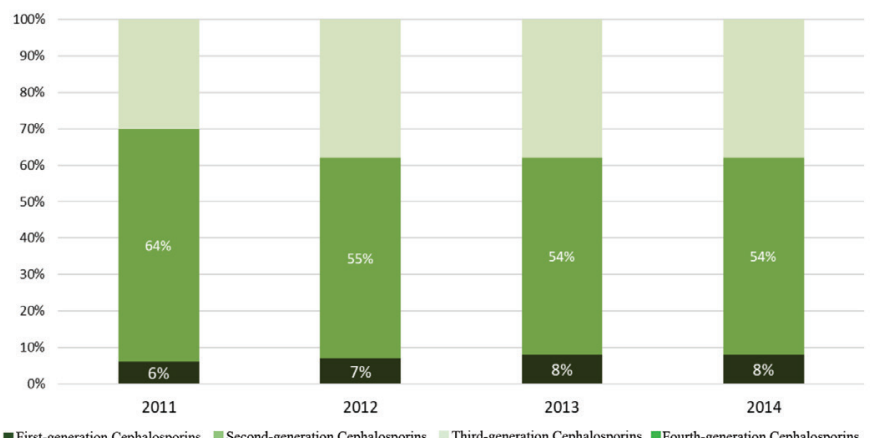

Figure 5. Rates of cephalosporin usage in Turkey between 20112014 province, the highest consumption occurred in the province of Hatay, with a DDD value of 49.12 , followed by Osmaniye with 47.69 DDD, Mersin with 46.64 DDD, Adana with 46.55 DDD, and Uşak with 46.14 DDD. Turkish provinces with the lowest antibiotic consumption were Hakkâri, with 19.40 DDD, followed by Muş with 22.18 DDD, Bitlis with 24.96 DDD, Tunceli with 25.02 DDD, and Ardahan with 25.21 DDD. Provincial antibiotic consumption is illustrated in a color density map in Figure 8.

In summary, drug utilization studies are conducted using the ATC/DDD system, which allows comparison of provinces, regions, and countries. This methodology was also used to

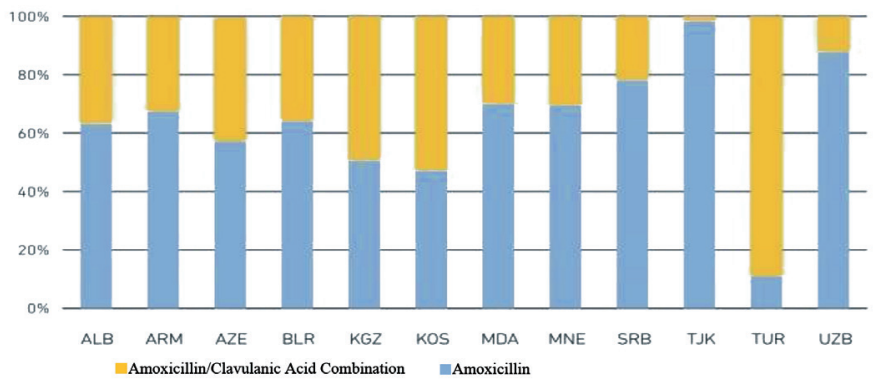

Figure 6. Rates of amoxicillin and amoxicillin/clavulanic acid usage $^{[37]}$

ALB: Albania, ARM: Armenia, AZE: Azerbaijan, BLR: Belarus, KGZ: Kyrgyzstan, KOS: Kosovo, MDA: Moldova, MNE: Montenegro, SRB: Serbia, TJK: Tajikistan, TUR: Turkey, UZB: Uzbekistan

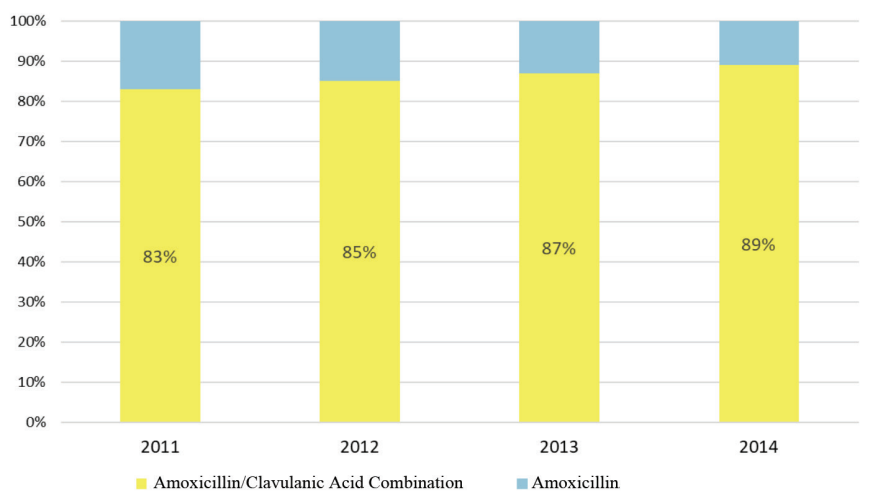

Figure 7. Rates of amoxicillin and amoxicillin/clavulanic acid usage in Turkey between 2011-2014

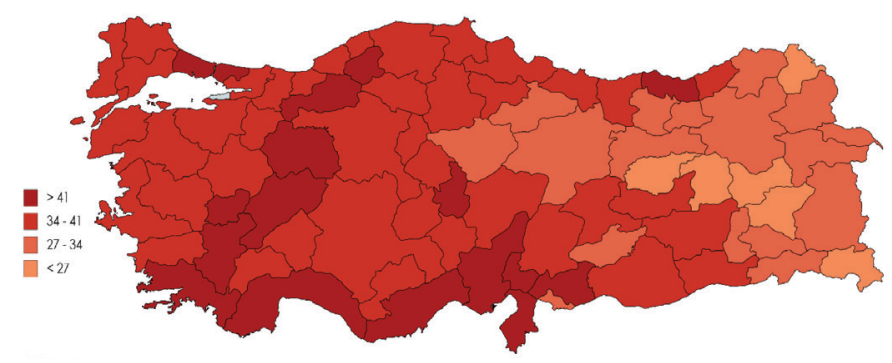

Figure 8. Color density map reflecting daily defined dose distributions of antibiotic consumption according to province 
determine consumption of the antibiotics discussed in this article. Antibiotic consumption data for Turkey are calculated with this methodology, shared with the WHO-AMC network via the TMMDA, and validated by the WHO. Although antibiotic consumption data for the years 2015-2016 were also calculated by the TMMDA, data pertaining to these years have not yet been validated by the WHO; therefore, this report includes detailed results from the years 2011-2014, which have been validated by the WHO. The fact that Turkey ranked first among the countries with which it was compared in the evaluation of antibiotic consumption in 2011 brought attention and increased awareness of this issue. Preventing excessive and unnecessary use of antibiotics is crucial in decelerating antibiotic resistance. Important responsibility in this area falls not only on all health professionals, especially our physicians and pharmacists, but also on the all parts of the society.

\section{Causes of Inappropriate Antibiotic Use}

There are basic factors to consider regarding antibiotic therapy. In order for an antibiotic to be effective in a patient, it must be used appropriately. Appropriate antibiotic use can be defined as a correct diagnosis followed by the administration of the correct drug, at appropriate doses and intervals, through an appropriate route, and for an appropriate duration. Before initiating antibiotic therapy, it should be determined whether antibiotic therapy is necessary, whether the patient's clinical presentation is consistent with an infectious disease, and if so, whether that infection is bacterial. In addition, appropriate microbiological samples should be obtained and the pharmacodynamic and pharmacokinetic properties of the antibiotic and compatibility with the patient's characteristics should be evaluated prior to treatment. After initiating treatment, it is necessary to monitor treatment response and to narrow or broaden the spectrum when necessary according to test results.

Inappropriate use of antibiotics is observed in many countries and can be related to various factors. The most important of these are summarized below.

\section{Use of Inappropriate Antibiotics in The Presence of Infection}

Inappropriately used antibiotics may also lead to high mortality rates ${ }^{[38,39]}$. In some cases, even if the patient needs antibiotic therapy, the antibiotic used may not be suitable for the indication. In a study on patients with Gram-negative bacteremia, appropriate treatment was found to improve prognosis, while inappropriate treatment resulted in longer hospital stays ${ }^{[40,41]}$. In another study it was found that 341 of 1064 patients with sepsis caused by Gram-negative bacteria died, most of those who died were given inappropriate initial antibiotic therapy, and the mortality rate was 3.9 times higher in this group ${ }^{[42]}$.
Antibiotics should be administered at appropriate dose and duration to patients who have been adequately evaluated and undergone the necessary tests. A sufficient amount of time should be allocated to properly evaluate the patient. The amount of time allocated to a patient is an important quality indicator. Unfortunately, quantity takes precedence over quality in many countries. This approach results in less time spent with each patient, and the subsequent substandard examinations reduce quality. For these reasons, patients are often given inappropriate antibiotics. A physician who is unsure about the patient and their disease cannot ascertain whether an infection is bacterial, and therefore views the prescribing of antibiotics as a safeguard.

\section{Unnecessary Combinations}

The combined use of antibiotics is necessary in rare cases (e.g., brucellosis, tuberculosis, etc.). Combination therapies are administered to reduce resistance and mortality. However, various studies conducted to date have demonstrated that combined therapies do not meet these goals ${ }^{[38]}$. Unnecessary combinations often lead to the unfavorable consequences of drug interactions. A study comparing the use of vancomycin monotherapy versus combined metronidazole + vancomycin for antibiotic-related diarrhea were compared showed that combination therapy was not superior to monotherapy and resulted in more adverse events ${ }^{[43]}$. For years, the necessity of combined therapies for Pseudomonas infections has been considered to be a rule. However, recent studies have failed to demonstrate superiority of combined therapies for this indication ${ }^{[44,45]}$.

\section{Unindicated Use of Antibiotics}

It is generally clear which antibiotics can be used for which conditions. However, sometimes certain antibiotics should not be used in certain patients due to patient-related factors, even if they have an appropriate indication. For example, a baby with brucellosis should not be treated with tetracycline. In addition, boundaries have not been clearly defined for all antibiotic indications. For instance, antibiotics are commonly selected based on patient characteristics in cases of sudden-onset shock. There is no evidence-based medical reference showing all antibiotic indications.

Another area in which antibiotics are used without indication is surgical prophylaxis. Many studies conducted in Turkey have revealed unnecessary prolongation of surgical prophylaxis, use of unnecessary combinations for prophylaxis, and prophylaxis with broad-spectrum antibiotics to be common errors ${ }^{[46]}$.

Prolonged prophylaxis is one of the common improper practices. The benefit of continuing antibiotics after a surgical intervention has not been scientifically proven. An additional antibiotic dose is not recommended, except for prolonged procedures and 
special patient groups who have blood loss or undergo fluid replacement ${ }^{[47]}$.

According to WHO data, more than $50 \%$ of drugs are prescribed inappropriately and nearly $50 \%$ of patients do not take their medication appropriately. Viral URTIs account for a substantial proportion of admissions to primary care centers. Although it is well known that antibiotics have no place in the treatment of viral infections, they are frequently used in clinical practice. The most common of these viral infections are colds, influenza, bronchitis, and viral gastroenteritis ${ }^{[48]}$.

A study evaluating antibiotic use in Kosovo determined that $50 \%$ of the 811 participants had used antibiotics within the last year, one quarter of which were obtained without a prescription ${ }^{[49]}$. The results also indicated that $24 \%$ of the antibiotics were used for influenza, 20\% for sore throat, and $13 \%$ for common cold. Interestingly, it was found that $43 \%$ of the participants believed that antibiotics were effective against viral infections.

Some recent studies in which antibiotics are approved through automation systems and on-the-spot training is provided meanwhile, have shown that the consumption and cost of antibiotics can be reduced by using hospital-based automated systems under the supervision of an infectious diseases specialist for antibiotic approval[50]. It has also been shown that de-escalation can be successfully achieved with a similar system in which blood cultures from hospital infections are integrated with the hospital automation system ${ }^{[51]}$.

\section{Pressure from Families to Use Antibiotics}

Educating the community on the appropriate use of antibiotics is at least as valuable as informing physicians ${ }^{[52]}$. Number of children, parents' age, and income level were identified as family-related factors affecting antibiotic use ${ }^{[53]}$. The socioeconomic level of a family is inversely proportional to their antibiotic consumption ${ }^{[54]}$. In one study, this relationship was compared between Spain and Denmark, and consumption was found to be higher in Spain. Moreover, it was found that while broader-spectrum antibiotics were consumed in Spain, narrowspectrum antibiotics like penicillin were more commonly used in Denmark ${ }^{[55]}$.

Families, especially mothers, attach great importance to past experience. Parents who have previously observed their child recover from a fever by using antibiotics tend to want to use antibiotics for every similar episode later and can be insistent about this toward physicians ${ }^{[5]}$. Similarly, parents who claim their febrile child is not improving sufficiently and demand re-evaluation can be more insistent about the prescription of antibiotics by physicians ${ }^{[57]}$. In a study conducted among family practitioners, it was shown that families who believed their children needed antibiotics put more pressure on physicians ${ }^{[58]}$.

It was reported that if maternal pressure to get antibiotics could be reduced, the amount of antibiotics prescribed to children could be reduced by nearly half ${ }^{[56]}$. In a study in which families were asked where they got information about antibiotics, the most common source was physicians, followed by television and relatives ${ }^{[53]}$. Communities' interest in and perception of antibiotics constitute another factor that influences antibiotic use. While the consumption of antibiotics for viral diseases such as colds and influenza are particularly low in Baltic countries, it is much higher in Middle Eastern countries ${ }^{[59]}$. Therefore, continuing education for both communities and physicians is important for the prevention of antibiotic consumption (Figure 9).
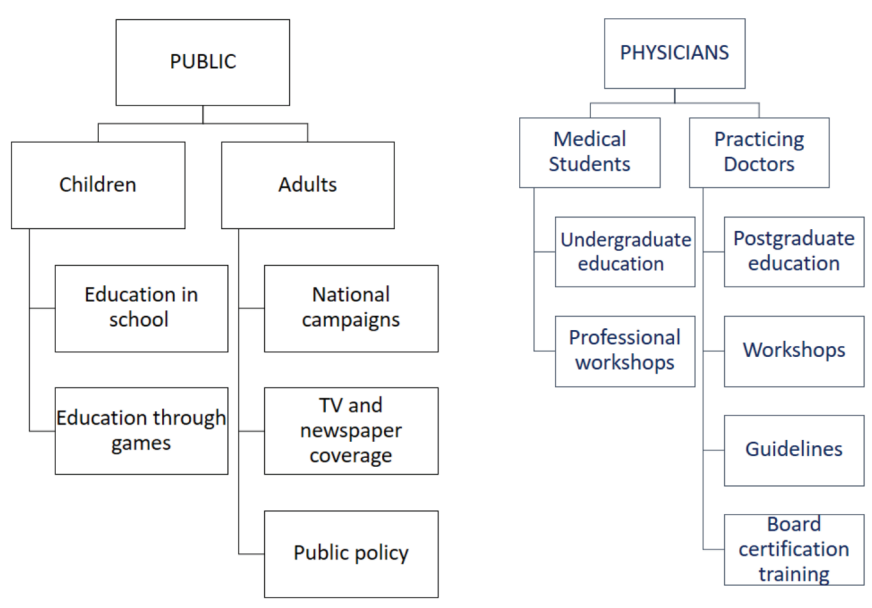

Figure 9. Relation between antibiotic consumption and the public and physicians

\section{Insufficient Laboratory Support Before Administering Antibiotics}

In order to prescribe the appropriate antibiotic, laboratory tests relevant to the disease must be performed firstly. Clinicians should gather enough evidence before giving antibiotics. Performing these tests is imperative before making the decision to use antibiotic therapy. Physicians who do not perform the necessary evaluations prescribe more antibiotics ${ }^{[60]}$. In Turkey, rapid antigen screening tests for group A streptococci are done at primary healthcare facilities throughout the country and are covered by social insurance. In addition, antigen testing for encapsulated bacteria is also performed for patients with suspected meningitis in many tertiary hospitals. In a study conducted in Gambia, it was observed that antibiotics were prescribed for one-third of patients with suspected infections and that $83 \%$ of inappropriately prescribed antibiotics lacked laboratory support ${ }^{[61]}$. If the clinicians conclude that the 
use of antibiotics is not necessary after routine testing of a patient presenting with signs of infection, they do not prescribe antibiotics ${ }^{[62]}$.

\section{Lack of or Non-adherence to Evidence-Based Guidelines}

The lack of national guidelines on antibiotic use is another factor contributing to inappropriate antibiotic consumption. In particular, guidelines for common antibiotic indications (e.g., diarrhea, urinary tract infection, URTI) prepared cooperatively by relevant associations and health authorities are extremely important for the prescription of appropriate antibiotics.

A study conducted in India showed that nearly $90 \%$ of newborns were started on antibiotics due to a pre diagnosis of sepsis, but that no evidence was sought as a basis for the initiation of antibiotics in these infants ${ }^{[63]}$.

Evidence-based guidelines are reported to reduce both antibiotic consumption and costs ${ }^{[6]]}$. There was an $11 \%$ decrease in the use of antibacterial agents and a $42 \%$ decrease in the use of antifungal agents in a 600-bed hospital that created guidelines for antibiotic therapy and prophylaxis. This resulted in a 27\% (319,300 USD) decrease in antibiotic costs in 1995 when compared to values from 1994.

\section{The Role of Pharmacists and The Pharmaceutical Industry in Inappropriate Use}

The use of antibiotics without prescription constitutes a major part of inappropriate usage. Antibiotic dispensing by pharmacies and inadequate regulation have been shown to contribute to excessive antibiotic use. A recent study conducted in Mexico determined that licensed pharmacists did not spend enough time at their pharmacies and that their assistants dispensed medicine and provided most patients information regarding the medicines ${ }^{[6]}$. It was also noted that these assistants received drug-related information from representatives of the pharmaceutical industry. Patients with low education level trusted pharmacy assistants and tended to follow their recommendations.

\section{Lack of an Effective Antibiotic Policy}

Antibiotic consumption is lower in societies that practice rational surveillance of antibiotic use. The presence of antibiotic surveillance systems and hospital formulas limit antibiotic consumption. Guidelines specifying which antibiotic should be used for which condition and for what duration are also essential for limiting antibiotic use ${ }^{[6]}$. Even providing feedback without any intervention significantly impacts antibiotic consumption. In one study, for instance, a 30\% reduction in quinolone use was achieved by giving feedback alone ${ }^{[57]}$.
9. Lack of Education on Antibiotics During and After Medical School

The education about antibiotics received by health personnel, especially doctors, is a factor in rational antibiotic use. Physicians, particularly surgeons, who receive adequate postgraduate training differ in their degree of compliance to antibiotic guidelines. Educational interventions such as compiling handbooks for surgeons, displaying informative posters in wards, and holding educational seminars increase compliance ${ }^{[68]}$. Similarly, surgeons who are educated on how prophylactic antibiotics should be used in surgery during their training have been shown to be more compliant with guidelines. Another study showed that physicians' knowledge of appropriate antibiotics was 9.74 prior to training during dental surgery education and increased to 18.16 after training ${ }^{[69,70]}$.

In summary, the need for strategies to reduce antibiotic resistance has become clear. Measures are needed to prevent the misuse of these drugs both in the community and by physicians. Cooperation of universities, the media, the $\mathrm{TMH}_{\text {, }}$ and nongovernmental organizations for this purpose is of key importance.

One Health in Antibiotic Resistance: The Role of Antibiotic Consumption in The Food and Animal Industries in Resistance and Necessary Measures

As in the health field, the inappropriate and widespread use of antibiotics in agriculture and livestock farming leads to the spread of resistance genes and therefore to an increase in the prevalence of infections due to MDR microorganisms. The One Health approach emphasizes that human, animal, and environmental health are interconnected and encourages comprehensive and integrated measures to prevent AMR.

1. The History of Antibiotic Use in Agriculture and Livestock Farming and its Impact on Resistance

Antibiotics are widely used for the prevention and treatment of bacterial infections in the fields of agriculture and industrial food animal production. In addition, the use of antibiotics as growthpromoting substances, especially in food-producing animals, is a highly controversial issue because it leads to the development of $\mathrm{AMR}^{[2]}$. The most reliable information on the overall production and use of antibiotics belongs to the US and EU member states. Seventy percent (15-25 thousand tons) of antibiotics produced in the US are used for nontherapeutic purposes in food animal production. In the US, antibiotic use in livestock production is 8-fold greater than health-related consumption. It has been estimated that at least 63,200 tons or more of antibiotics have been used in farm animals worldwide since 2010. The growing global population and resulting demand for food will also increase the use of antimicrobials in livestock farming ${ }^{[7]}$. A projection 
made accordingly showed a predicted increase of $67 \%$ between 2010 and 2030 $0^{[72]}$.

In the US, low-dose antibiotics were first used as growthpromoting agents in the years following World War 2. At that time, meeting the need for animal protein and ensuring food security (hunger prevention) were perceived as more important existential threats than the possibility of AMR. Since growth results were quite impressive, the use of high antibiotic concentrations $(200 \mathrm{~g} /$ ton $)$ in animal feeds was quickly adopted worldwide ${ }^{[73]}$. The selection of resistance genes due to widespread antibiotic use and the spread of these resistance genes among farm animals due to close captivity resulted in the emergence and spread of a resistant Salmonella typhimurium strain in the mid-1960s ${ }^{[74]}$. The matter was considered to be a public health issue due to infection transmission to farm workers who cared for infected cattle, to veterinarians, and even to individuals who consumed the milk of infected cattle during this period. The Swann committee, appointed by the United Kingdom Ministry of Agriculture and Health, advised that antibiotics not be used for non therapeutic reasons such as growth promotion and that joint commissions responsible for human and animal health be formed. Although the British government did implement some of these recommendations, it took many years to adopt and implement them due to political opposition in the areas of agriculture and pharmacology and the influence of the pharmaceutical industry ${ }^{[7,75]}$. Twenty years later (in 1986), Sweden was the first country to heed the Swann committee reports and prohibit the use of antibiotics as growth promoters in livestock farming.

The main antibiotics used as animal feed additives are bambermycin, bacitracin, monensin, salinomycin, virginiamycin, tylosin, spiramycin, avilamycin, avoparcin, ardacin, efrotomycin, olaquindox, and carbadox. Because a significant portion of these antibiotics are used for treatment or prophylaxis of infections in humans, we may make certain inferences. These agents are used as growth factors. Avoparcin used in animal feed induces crossresistance to vancomycin and teicoplanin, which are drugs from the same group that are used therapeutically in humans. The isolation of vancomycin-resistant enterococci (VRE) is common in animals that consume feed containing avoparcin ${ }^{[71,74]}$.

In 2006, the use of antibiotics in animal feed was completely prohibited in all EU countries ${ }^{[76]}$. Unlike European countries, the US never approved the use of avoparcin as a growth factor in food animal farming due to concerns that it could be carcinogenic. Thus, the epidemiology of VRE in the US is quite different. Resistance surveillance in humans and food animals has been integrated through the NARSS and National Animal Health Surveillance System, and VRE has not been detected in animals in the United States since 2002 $2^{[77,78]}$.

\section{Animal-to-Human Transmission of Resistant Microorganisms}

Resistant pathogens can be transmitted to humans through the consumption of contaminated food animals and animal products. Interspecies modes of transmission include direct contact with infected animals, consumption of contaminated animal-based foods (meat, fish, poultry, dairy products, etc.), and indirect contact with animal waste due to contamination of water sources. Contact with food resulting from the use of animal waste as fertilizer is also a factor in transmission ${ }^{[78,79]}$.

Many resistant bacteria and resistance genes have been detected in animal source foods in recent studies ${ }^{[0,81]}$. The presence of resistant pathogens in food is a major public health problem. Food-producing animals are the primary reservoirs of zoonotic pathogens. The most common resistant pathogens that can be transmitted through milk and dairy products include S. aureus, E. coli, Listeria monocytogenes, and Salmonella spp. S. aureus is one of the leading causes of foodborne illness and its enterotoxigenic strains can contaminate meat and dairy products. An analysis of 2,650 milk samples revealed that $12.4 \%$ were contaminated with $S$. aureus and $16.2 \%$ of those strains were MRSA. There are also reports of penicillin and oxacillin-resistant $L$. monocytogenes and resistant Salmonella spp. detected in milk and dairy products. In a study conducted in Ethiopia, MDR Salmonella spp. were detected in $10.7 \%$ of cattle ${ }^{[82]}$. Plasmid-mediated colistin resistance transferred via the mcr-1 (mobilized colistin resistance-1) gene was first documented in $E$. coli in 2015. The more frequent detection of isolates carrying the mcr-1 gene in animals and animal source foods in many countries demonstrated that the resistance originated in animals. The widespread use of colistin in pigs and fowl is believed to have contributed to the selection of this resistance ${ }^{[83]}$. When one considers the importance of colistin in the treatment of infections due to MDR Gram-negative pathogens, the scale of the problem is clearer. To reduce further spread of resistance, regardless of its origin, a global one-health approach should be adopted and strong antibiotic stewardship programs should be implemented. Within this framework, unnecessary colistin use in animals and humans should be reduced, infection control measures should be taken, and colistin use and resistance should be monitored in both human and veterinary medicine. The problem of antibiotic resistance is reported to be especially common in developing countries, where regulations on antimicrobial use are usually insufficient. With evidence demonstrating the transmission of resistant pathogens from animals to humans, this issue has been addressed as a global public health concern and various guidelines on recommended solutions have been published ${ }^{[84]}$. 


\section{Strategies for Preventing Antibiotic Resistance in Veterinary Medicine}

Strategies to prevent antibiotic resistance at individual, community, local, regional, national, and international levels should be determined, and regulations should be implemented via global cooperation. Essentially, all strategies aim to ensure the rational use of antibiotics, prevent the non-therapeutic use of antibiotics in food animals, deter the sale of antibiotics without prescription, and monitor resistance data through integrated surveillance systems. To achieve these objectives, the WHO, World Organization for Animal Health (OIE), and the Food and Agriculture Organization of the United Nations have adopted the One Health approach. In 2015, the WHO prepared a Global Action Plan to tackle the problem of AMR.

An electronic prescription system has been introduced in Turkey for drugs used in human medicine to ensure the rational use of antimicrobials. Similarly, it was decided to introduce an e-prescription and drug monitoring system for drugs to be used in animal health services. A pilot program was launched in 2017 and it was decided to also expand the program across Turkey starting in the year 2018.

Another factor that plays a role in the development of AMR is the long-term exposure of pathogens to suboptimal doses of antibiotics and the selection of resistant pathogens as a result of the non-therapeutic use of antibiotics on food animals. In a 2012 study by the OIE, it was found that only $27 \%$ of OIE member countries had official monitoring systems in which antimicrobial use in livestock farming could be recorded ${ }^{[85]}$. The 2017 WHO guidelines on the use of medically important antimicrobials in food animals advised completely restricting the use of medically important antibiotics on healthy animals for growth promotion and disease prevention both in the food industry and at the farm level. It was also weakly recommended that critically important antibiotics for human medicine not be used even for therapeutic purposes in food animals ${ }^{[85]}$.

In conclusion, future studies on the prevention of AMR should be conducted with a "one health approach" under the oversight of a single center to facilitate "coordination". This problem cannot be solved with a short-term approach. Therefore, studies should be carried out with "decisively" to tackle long-term challenges.

\section{Antimicrobial Stewardship Programs}

The rapid increase in AMR rates, the emergence of MDR and even pandrug-resistant bacteria (superbugs), and the scarcity of newly discovered or developed antibiotics require the implementation of more comprehensive, coordinated, multifaceted, and interdisciplinary programs ${ }^{[86]}$.
In the US, healthcare-related infections caused by MDR bacteria are reported to cause an additional direct expenditure of US $\$ 20$ billion and indirect expenditure of US $\$ 35$ billion $^{[87]}$. The efforts on the prevention and control of antibiotic resistance that were initiated in 2014 under former US president Obama culminated in the preparation of a national action plan in 2015.

While it is impossible to completely prevent the emergence of antibiotic resistance, it can be reduced and controlled by acting in accordance with proper policies. While some of these necessary measures require international cooperation, there are also actions to be taken at an institutional level[88].

One of the most important long-term strategic measures against the development of resistance is the implementation of ASP. ASP encompasses interventions to ensure that the most appropriate antimicrobial (the agent that is most appropriate to treat the relevant infectious disease and will cause the least secondary 'collateral' damage) is administered at the appropriate dose, for the appropriate duration, and through the appropriate route, and all of the processes that facilitate them ${ }^{[32,40]}$. The basic principle for achieving the expected success in an ASP is implementing infection prevention and antimicrobial stewardship together ${ }^{[89]}$.

In the early years when antibiotic resistance was first detected, the issue was raised by merely stating that there was a problem; in later years, the concepts of appropriate antibiotic use (1970), antimicrobial management, and antibiotic control program emerged, cumulating in recent years with the search for a solution to the problem through $\mathrm{ASPs}^{[00]}$.

Approximately one-third of all hospitalized patients worldwide use antibiotics, 30-50\% of which are inappropriately used [e.g., incorrect choice of antibiotic, use of antimicrobial agents to which resistance has developed, excessive or inadequate treatment (in terms of spectrum, duration, or dose)] ${ }^{[85]}$.

With an effective ASP, resistance is reduced over time and there are also decreases in adverse effects in patients and antibiotic-related costs. The proportion of total cost attributed to antibiotics, which is around 30\% of hospital expenditures, can be reduced to $10 \%$.

The aim of ASPs is to improve the quality of antibiotic prescribing practices in order to promote the appropriate and rational use of antibiotics. The objectives set for achieving this goal are presented in Table 9.

\section{Antibiotic Stewardship at The National Level}

Turkey has one of the highest antibiotic consumption and resistance rates in Europe. Efforts to deal with these issues have been initiated in various units of the $\mathrm{MH}$. 
ASPs should be planned at the national and health institution level and be implemented through the relevant institutions. The $\mathrm{MH}$, which is the national health authority, must take action and work in conjunction with the Ministry of Food, Agriculture and Livestock. Better and more effective nationwide implementation of an ASP requires the backing of the Governance of Turkey and close cooperation with all stakeholders, including the relevant ministries and universities that include departments in the health sciences fields, such as medicine.

Table 10 summarizes national priorities of Turkey for an ASP within the context of global experiences ${ }^{[90]}$.

Of the successful remedial actions that have been implemented globally within the scope of ASP, the most significant are the education of service providers and the public; continuous monitoring, evaluation, and feedback regarding prescriptions (surveillance mechanism); and national drug policies (restrictive policies) regarding pricing, reimbursement, and use of drugs.

Antimicrobial Stewardship in Hospitals/ Healthcare Institutions

The basic elements of ASPs in hospitals include resistance surveillance, ensuring the appropriate use of antibiotics, and implementing effective infection prevention and control programs. Necessary steps for the implementation of ASPs are summarized in Table 11, and the practices employed within ASPs in Table 12.

A dedicated Antimicrobial Stewardship Team should be established to ensure implementation of the practices specified in Tables 11 and 12. This team must be multidisciplinary (Table 13) ${ }^{[38,89]}$.

The ideal combination of members for an antimicrobial stewardship team is shown in Table 13; the key members are

Table 9. Main objectives of antimicrobial stewardship programs

\begin{tabular}{l}
\hline Objectives of antimicrobial stewardship \\
\hline 1. To help reduce antimicrobial resistance \\
- Combined implementation of effective antimicrobial stewardship \\
+ comprehensive infection control program (integrated measures = \\
"bundle") \\
2. To limit infection transmission, reduce antimicrobial resistance \\
3. To promote the appropriate use of antimicrobials \\
- Correct choice, duration, dose, timing, and route of administration \\
4. To help patients receive effective treatment and better clinical \\
outcomes \\
- To reduce the emergence of antimicrobial resistance \\
- To limit drug-related adverse events \\
- To minimize the risk of unintended consequences \\
5. To reduce antimicrobial costs without sacrificing patient \\
outcomes (secondary purpose)
\end{tabular}

Table 10. Nationwide actions necessary for antimicrobial stewardship programs

Nationwide actions necessary for antimicrobial stewardship
1. Create a national committee/board
- Multidisciplinary composition: Infectious Diseases, Clinical
Microbiology, Clinical Microbiology, Pediatric Infection, General
Surgery, adult/pediatric/neonatal intensivists
- Specialists from the Ministry of Food, Agriculture and Livestock
(veterinarians, etc.)
- Pharmaceutical industry representative(s)
- Food and livestock production sector representatives
2. Investigate the use of antimicrobial agents and resistance
patterns in the community, health institutions, veterinary
institutions, and agriculture
- "Antibiotic consumption monitoring system" in the fields of
human and veterinary medicine
- "National antibiotic resistance monitoring system"
3. Organize national and regional educational programs
- For physicians, pharmacists, nurses, veterinarians, and the public
4. Prevent over-the-counter sales of antibiotics
5. Improvement and supervision of infection prevention and control
programs
6. Cooperation with international organizations and the
pharmaceutical industry
7. Necessary financial support for research

Table 11. Implementing antimicrobial stewardship in hospitals

Antimicrobial stewardship in hospitals

- Preparation of hospital guidelines and a guide for antibiotic use

- Antimicrobial resistance surveillance and the reporting of analyzed results

- Education on antibiotic use for clinicians

- Restriction of antibiotic use

- Regular consultation with infectious diseases department

- Monitoring compliance with the antibiotic control program and providing clinicians feedback

Table 12. Antimicrobial stewardship practices

\begin{tabular}{l}
\hline Practices constituting antimicrobial stewardship \\
\hline - Prospective audit with feedback \\
- Restriction and approval \\
- Education \\
- Preparation of guidelines \\
- Antibiotic rotation \\
- Antibiotic "order forms" \\
- Antibiotic combinations \\
- "De-escalation" (step-down antimicrobial therapy) \\
- Optimal dose \\
- Consecutive therapy
\end{tabular}


infectious disease and clinical microbiology specialists and a clinical pharmacist. Considering the institutional structuring and role of hospital infection control nurses in surveillance in Turkey, it is imperative that they are represented in the team as well. The antimicrobial stewardship team would most appropriately be structured as an Antimicrobial Stewardship Subcommittee within the Hospital Infection Control Committees in Turkey.

\section{Criteria for Evaluating an ASP}

In order to evaluate the effect of ASP-related interventions/ practices on antibiotic use, it is important to measure antibiotic use (e.g., total amount of antibiotics used, target amount of antibiotic use, duration of treatment, rates of oral/intravenous administration, drug expenditures) and outcomes relevant to antibiotic change (e.g., cost, number antibiotic use days, changes in prescribing practices for certain antibiotics, changes in status of MDR bacteria or $\mathrm{C}$. difficile). Relevant measures also allow for benchmarking between institutions. Applicable measures pertaining to the issue are summarized in Table $14^{[91,92]}$.

Informatics and technology must be utilized to effectively implement ASPs, obtain evaluation measures and enable intraand interinstitutional comparison, enable digital record-keeping and data analysis, and to provide clinical decision support ${ }^{[93]}$.

In summary, the effective nationwide implementation of ASPs is possible with close and continuous collaboration between

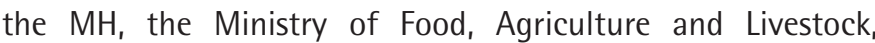
and universities with faculties of medicine and/or other health sciences, carried out under the auspices of the Turkish Government. The international relations aspect of the issue should also be considered during this process.

Basic Recommendations for The Rational Use of Antibiotics

The main infection control measures practiced in hospitals and the community globally and in Turkey include expanding immunization programs, notifying infectious diseases,

Table 13. Members of a hospital antimicrobial stewardship team

- Hospital director
- Infectious diseases and clinical microbiology specialist
- Internal medicine specialist
- Surgeon
- Pediatrician
- Clinical microbiology specialist
- Pharmacologist
- Hospital pharmacist (clinical pharmacist)
- Information systems specialist
- Epidemiologist
- Hospital infection control nurse

monitoring hospital infections, certifying physicians and nurses, and establishing infection control committees.

Basic recommendations for the rational use antibiotics can be listed as follows:

\section{Determine the indication for antibiotic use}

Detailed history-taking and meticulous physical examination should be conducted for each patient. The focus of infection should be investigated and the indication for antibiotic use should be clarified. Antibiotics should not be given in the absence of clinical findings indicative of bacterial infection. Detecting the causative microorganism and providing pathogen-specific therapy are the cornerstones of treatment. Empirical antibiotic therapy is used in severe infections such as sepsis, acute bacterial meningitis, and febrile neutropenia where waiting for culture results may lead to unfavorable outcomes, and in infections for which cultures cannot be easily obtained, such as sinusitis and otitis. The aim of prophylactic treatment is to reduce or eliminate risk by administering antibiotics before an infection develops. Compliance with recommendations set forth in guidelines for surgical or non-surgical prophylaxis is important ${ }^{[94]}$.

2. Obtain the necessary clinical samples before initiating antibiotic therapy

Identifying the causative microorganism will ensure that the appropriate antibiotic is administered at the appropriate dose and will enable optimization of treatment duration. Clinical samples must be obtained at the right time, from the appropriate sites, and in necessary quantities for microbiological examination, and should be delivered to the microbiology laboratory as quickly as possible under proper transport conditions. Bacterial growth in cultures should be

Table 14. Criteria used to evaluation an antimicrobial stewardship program

1. Use of local antibiograms

2. Monitoring resistance patterns

3. Patient outcomes:

- Hospital length of stay

- Mortality

- Adverse events

- Readmission due to infection

4. Total antimicrobial use [DOT (Days of therapy) vs. DDD (Defined Daily Dose per 1000 PD)]

5. Costs of implementing the antimicrobial stewardship program

6. Costs of medication

7. Costs associated with drug-related adverse events

8. Costs of suboptimal antimicrobial therapy

9. Transition from intravenous to oral therapy

10. Number of interventions and percentage of recommendations implemented 
evaluated in terms of being the actual infectious agent, and the possibility of colonization or contamination should also be considered. Results obtained with unnecessary cultures or samples with insufficient quality may lead to the misuse of antibiotics ${ }^{[95,96]}$.

3. Plan empirical antibiotic therapy according to focus of infection, host characteristics, and local microbiological data

Disease severity, the patient's characteristics (age, allergy history, underlying diseases, pregnancy, breastfeeding status, immune resistance, predisposition to a disease), history of antibiotic use, history of colonization with MDR bacteria, source of infection (community- or hospital-acquired), the use of invasive tools, possible pathogens, and knowledge of regional and institutional microorganism resistance profiles should be guiding elements of empirical therapy. In serious lifethreatening infections, appropriate antibiotic therapy should be initiated within the first hour. When initiating antibiotic therapy, the clinical diagnosis, recommended antibiotic, and its dose and duration should be written in the patient file ${ }^{[97]}$.

4. Know the pharmacokinetic and pharmacodynamic properties of an antibiotic in order to provide the right antibiotic through the most appropriate route, at the most effective dose, and for the most effective duration

In order for treatment to be successful, an antibiotic with demonstrated in vitro activity against the targeted microorganism must be present at therapeutic concentrations at the infection site. Lipophilic antibiotics have high oral absorption, large volume of distribution, and rapid cellular uptake, and are metabolized in the liver. Therefore, they are effective against intracellular pathogens. They can also reach high concentrations in damaged tissues with limited perfusion. Hydrophilic antibiotics, on the other hand, have a low volume of distribution, low cellular uptake, and are excreted unaltered via the kidneys. It should be kept in mind that with antibiotics that show high degrees of protein binding, such as ceftriaxone, ertapenem, daptomycin, and teicoplanin, changes in patients' protein levels may influence antimicrobial activity. Antibiotics exert a time-dependent or concentrationdependent bactericidal effect. For drugs with time-dependent action (like beta-lactam antibiotics and linezolid), the duration for which the patient's serum antibiotic level remains above the minimum inhibitory concentration (MIC) reported for the pathogen (time above MIC; T>MIC) is responsible for the bactericidal effect. Antibiotics with time-dependent action are administered at frequent intervals or with long infusions to maintain concentrations above the MIC for as long as possible. For antibiotics with concentration-dependent bactericidal action, like aminoglycosides and daptomycin, the highest achievable serum concentration $\left(\mathrm{C}_{\max } / \mathrm{MIC}\right)$ is responsible for the bactericidal effect. The goal is to administer the highest possible antibiotic dose at the beginning for maximum bactericidal effect. Increase in serum concentrations of concentrationdependent antibiotics also extends their postantibiotic effect periods. With fluoroquinolone, polymyxin, and tetracycline group antibiotics, the time under the curve above the MIC in 24 hours $\left(\mathrm{AUC}_{0-24}\right)$ is important ${ }^{[97]}$.

5. Select preferentially antibiotics with low risk of causing collateral damage

Collateral damage is defined as the unwanted effects of antibiotics on bacterial ecology. All antibiotics can lead to the selection of resistant strains. However, this effect is stronger with some antibiotics, pharmacokinetic and pharmaceutical properties of which play an important role in collateral damage. Third-generation cephalosporins, fluoroquinolones, and carbapenems are the antibiotics most commonly associated with more collateral damage. Aminoglycosides, beta-lactam/betalactamase inhibitors, and macrolides, on the other hand, are among the antibiotics with lower risk of collateral damage ${ }^{[97,98]}$.

\section{Rarely resort to the use of combined antibiotic therapies}

Combination therapies are used to provide broad spectrum activity in cases of severe infections with unidentified focus, to achieve synergism, to retard the development of antibiotic resistance, and to reduce relapse rates in certain diseases. Pseudomonas aeruginosa, Acinetobacter baumannii, and K. pneumoniae are the most common MDR or pan resistant pathogens detected in hospitals. The use of combination therapies is recommended for patients who develop severe sepsis/septic shock due to these MDR pathogens and for immunocompromised or febrile neutropenic septic patients and septic patients hospitalized in ICUs. Randomized clinical trials investigating the efficacy of combination therapies currently in use are needed ${ }^{[94,99]}$.

\section{Rapidly eliminate or control the focus of infection if} possible

In cases with an identifiable focus of infection, such as necrotizing soft tissue infections, abscesses, or cholangitis, the source should be eliminated or controlled. Ideally, source control should be achieved within 12 hours in septic patients. Removal of central venous catheters infected with Gram-negative bacteria, S. aureus, enterococci, Candida, and mycobacterial infections is recommended. If blood culture is still positive after 72 hours despite appropriate antibiotic therapy initiated to spare the catheter, the central venous catheter should be removed ${ }^{[96]}$.

8. Reevaluate patients within $48-72$ hours based on the results of cultures, rapid tests, and molecular tests

The patient should be reevaluated after 48-72 hours of treatment in order to determine whether antibiotics are still 
needed, whether treatment should be switched to narrower/ broader spectrum antibiotics, and to consider switching to oral treatment or outpatient parenteral antibiotic therapy. Oral antibiotic therapy should be preferred because it reduces complications related to vascular access. Furthermore, it is cost-effective, and hastens patient discharge ${ }^{[97]}$.

\section{Administer antibiotics for the minimum duration that provides maximum effect}

Short-term treatment increases patient satisfaction and treatment compliance and reduces adverse effects and cost. Although treatment duration varies according to the microorganism and the patient's treatment response, 4-7 days is considered sufficient for intra-abdominal infections where source control has been achieved. In the medical literature, it is reported that 7-10 days of treatment is sufficient for complicated urinary tract infections or acute pyelonephritis requiring hospitalization, 5-7 days is sufficient for community-acquired pneumonia, and eight days is sufficient for ventilator-associated pneumonia. Procalcitonin is an important marker that can guide clinicians in the timing of antibiotic discontinuation ${ }^{[100]}$.

\section{Stories of Success in Reducing Antibiotic} Resistance

The association between the excessive and inappropriate use of antibiotics and the development and spread of resistance has been clearly demonstrated. Due to the difficulty of developing new antibiotics, the most reasonable solution is effective management of antibiotic use ${ }^{[101]}$. Global solutions are needed for the AMR problem. Antimicrobial stewardship is the cornerstone of this solution ${ }^{[102]}$. However, although antimicrobial stewardship is crucial for the prevention and reduction of antibiotic resistance, it should not be considered a solution on its own; it must be implemented in conjunction with strict infection control measures ${ }^{[103]}$. Reduction in the use of all antibiotics and of specific antibiotic groups, reduction in the incidence of infections that develop due to MDR microorganisms (most importantly), and ultimately a reduction in mortality demonstrate the success of antimicrobial stewardship ${ }^{[95]}$. The WHO defines appropriate antibiotic use as having the maximum clinical and therapeutic effect in a cost-effective way while minimizing drug-related toxicity and the development of $\mathrm{AMR}^{[104]}$. The Infectious Diseases Society of America issued an evidence-based medical guideline for the improvement of ASPs in hospitals. This guideline aimed to prevent the selection of pathogenic microorganisms and the emergence of resistance ${ }^{[105]}$. This section includes stories from different countries around the world that implemented and had success with ASPs.

\section{Australia}

An ASP has been effectively implemented in Australian hospitals. The healthcare quality and safety commission of the Australian government conducts AMR surveillance and determines priority indications for the use of antibiotics. Since 2013, antimicrobial stewardship has been used as the accreditation criteria of healthcare centers ${ }^{[05]}$. In guidelines prepared as a result of early recognition that fluoroquinolones have an important effect on the selection and spread of AMR, this drug is presented as an alternative option and its use is restricted to very specific indications. As a result, Australia has the lowest quinolone use among high-income countries (0.6 DDD/1000 inpatient days vs. 1 DDD/1000 inpatient days in other European countries). The rate of resistance in E. coli isolates in community-acquired infections is 5.2\%, whereas this rate is around $15 \%$ in most European countries ${ }^{[106]}$.

\section{France}

France is one of the European countries with the highest outpatient antibiotic use. Three national action plans for the appropriate use of antibiotics were prepared within the past two decades (2001-2005, 2007-2010, and 2011-2016) ${ }^{[107]}$.

\section{Scotland}

The Scottish government established the Scottish Antimicrobial Prescribing Group in 2008, enabling the implementation of the national ASP in all healthcare institutions in the country. The main goals of this national program were to reduce or prevent further increase of AMR, achieve good clinical results in infectious diseases, reduce the toxic effects of antibiotics, and reduce rates of $C$. difficile infection (CDI), which was an epidemic in the country during that time. The use of four antibiotic groups was decreased (cephalosporins, ciprofloxacin and other quinolones, coamoxiclav and clindamycin), while priority was given to older antibiotic groups (co-trimoxazole, amoxicillin, tetracyclines, and aminoglycosides) for necessary indications ${ }^{[108]}$. Following this practice, there was a significant reduction in the proportion of antimicrobials associated with CDI used in primary care, from 38\% in 2009 to $20.5 \%$ in $2012^{[109]}$. Similarly, when Gram-negative bacteremia agents were evaluated, it was reported that the rate of ESBL production had decreased in E. coli strains, from 7.5\% in 2009 to $6.6 \%$ in 2012, as well as in K. pneumoniae, from 8.8\% in 2009 to $6.4 \%$ in $2012^{[109]}$.

\section{South Africa}

There are few data related to AMR epidemiology, rates of antibiotic use, and antimicrobial stewardship practices on the African continent. The ASP that was introduced after the threat of carbapenemase-producing Enterobacteriaceae appeared in 
the largest private hospital group in South Africa has been implemented in 55 hospitals since 2010. Multidisciplinary workshops and teleconferences were held and guidelines were created as part of this program. Within the first three months of implementation, a significant reduction in the use of all antibiotic groups was reported $(12.1 \%$ reduction $\mathrm{DDD} / 1000$ patient days $)^{[95,110]}$. However, the rate of antibiotic use in the country is still high due to the fact that the program has only been implemented in private hospitals.

\section{Sweden}

Sweden is one of the first countries in the world to implement a national ASP that includes the veterinary sector. Due to the STRAMA (Swedish Strategic Programme Against Antibiotic Resistance) program introduced in 1995, Sweden has one of the lowest levels of antibiotic use in the European countries ${ }^{[111]}$.

In a study evaluating the first 10 years of the STRAMA program, the program was reported to be very effective in reducing total antibiotic use and preventing the spread of resistant microorganisms when implemented in combination with other infection control measures ${ }^{[112]}$.

\section{United States of America}

The US was the first high-income country to educate the public using antibiotic campaigns. The CDC's "Get Smart" program was launched in 1995. Although these campaigns did result in a reduction in antibiotic use, especially in the pediatric and adult age groups, the unnecessary use of broad-spectrum antibiotics, particularly macrolides and quinolones, is still common ${ }^{[95]}$. The Transatlantic Task Force on Antimicrobial Resistance (TATFAR) was established in a summit meeting held in 2009 to address the problem of AMR, which had become a growing and dangerous public health issue. With the CDC's "Get Smart" program and the ECDC's "Antibiotic Awareness Day" campaigns, the US and EU began to act in coordination. In 0ctober 2011, 17 recommendations against AMR were defined. These recommendations can be reviewed under three main categories. They state that the problem of AMR requires urgent attention focused on the appropriate use of antimicrobials in the fields of human and veterinary medicine, the prevention of healthcare-associated and community-acquired MDR infections, and support for the development of new antimicrobials. Future studies will demonstrate to what extent the TATFAR program is reaching its goals.

\section{Turkey}

The Budget Execution Directive, introduced in Turkey in 2003, aims to limit the inappropriate use of antibiotics. Studies on the effects of the restriction policy have demonstrated a significant reduction in the amount of antibiotics used and a decrease in resistance rates ${ }^{[113-115]}$.
In short, effective ASPs play a key role in preventing the emergence and spread of MDR microorganisms. Antimicrobial stewardship practices are being successfully implemented in various regions and under different socioeconomic conditions.

Interventions That are Unsuccessful in Reducing Antibiotic Resistance, with Examples

While some interventions aimed at reducing AMR have been effective, others have failed. Of the interventions with questionable effectiveness at reducing AMR, the main ones include antibiotic rotation, antibiotic combination, and campaigns for reducing antibiotic consumption.

\section{Antibiotic Rotation}

This approach is based on the principle of periodically changing the antibiotics or antibiotic groups to be used in empirical treatment. There are studies showing that antibiotic rotation is effective at reducing AMR, as well as studies that report otherwise. A study conducted in intensive care patients showed that the cyclic use of antibiotics did not cause a significant change in antibiotic resistance among Gram-negative bacteria ${ }^{[116]}$. There are also studies reporting that the practice of antibiotic rotation has no favorable effect on the prevalence of VRE ${ }^{[116-118]}$. In one study conducted in an intensive care unit, rotational antibiotic administration was found to offer no benefit in terms of $A M R^{[117]}$. It has also been suggested that antibiotic rotation will not reduce resistance rates, but only cause fluctuations in resistance ${ }^{[119]}$. A recent comprehensive study conducted in eight intensive care units in six countries showed that antibiotic rotation did not reduce AMR in Gramnegative bacteria ${ }^{[120]}$. It should be kept in mind that antibiotic rotation also entails various risks. In fact, it was reported in one study that an outbreak of resistant $P$. aeruginosa occurred while practicing antibiotic rotation ${ }^{[120]}$. Based on these studies, it can be concluded that antibiotic rotation does not lead to reduced AMR in bacteria and is an unsuccessful intervention in the struggle against antibiotic resistance ${ }^{[121,122]}$.

\section{Antibiotic Combination}

Combined antibiotic therapy may reduce antibiotic resistance by providing a broad spectrum and preventing the formation of resistant subpopulations through multiple mechanisms of action. Antituberculosis therapy is one example of this ${ }^{[123,124]}$. However, the effects of antibiotic combinations on the development of resistance in hospital infections are debatable, and some studies have even reported the possible emergence of MDR strains ${ }^{[125,126]}$. The therapeutic efficacy of combination therapy regimens on clinical outcomes is also controversial ${ }^{[127]}$. Therefore, with a few exceptions, combination therapies may be considered an unsuccessful intervention for reducing antibiotic resistance. 


\section{Campaigns for Reducing Antibiotic Consumption}

Different campaigns have been and are still being organized in various countries around the world to reduce antibiotic consumption. One of the objectivestargeted by thesecampaigns is the reduction of cumulative antibiotic use to prevent AMR and reduce the prevalence of MDR microorganisms. However, such campaigns aimed at reducing total antibiotic use have questionable effectiveness in terms of reducing antibiotic resistance. A study conducted in France examined a campaign for the reduction of antibiotic consumption that was carried out between the years 2002 and 2003 ${ }^{[128,129]}$. The study showed that although antibiotic consumption decreased in these years, rates of methicillin resistance increased in both community and hospital Staphylococcus isolates. In a review of 22 campaigns targeting the public and physicians in high-income countries between the years 1990-2007, it was stated that these campaigns reduced antibiotic use but that their impact on antibiotic resistance was not clearly evaluated ${ }^{[130]}$. For this reason, campaigns for the reduction of antibiotic consumption should be carried out in coordination with other stakeholders (hospital, community, veterinary, and agricultural practices, etc.). Not only total antibiotic consumption, but also changes in class-specific antibiotic use and bacterial resistance should be monitored during and following these campaigns. Several practices have been implemented in Turkey over the past 20 years. Preferably, the campaigns that are being planned and executed in Turkey should also be carried out in consideration of the data in the aforementioned review ${ }^{[130]}$. Major interventions conducted to decrease antibiotic consumption in Turkey are summarized in Table 15.

Table 15. Interventions targeting antibiotic consumption in Turkey

\begin{tabular}{|c|c|c|}
\hline Intervention & Date & Comment \\
\hline NosoLINE project & 1996 & $\begin{array}{l}\text { The NosoLINE project, initiated in } 1996 \text { with the participation of more than } 50 \\
\text { institutions, was one of the important steps taken for hospital infection control studies }\end{array}$ \\
\hline Turkish Drug Guide & 1999 & $\begin{array}{l}\text { The guide, published in 1999, was recommended to physicians and pharmacists. The } \\
\text { Ministry of Health provided support for many educational activities related to RDU, } \\
\text { most of which were organized by the ministry itself, but a certain proportion of which } \\
\text { were organized by various non governmental organizations }\end{array}$ \\
\hline Antibiotic restriction & 15.02 .2003 & $\begin{array}{l}\text { The first national antimicrobial restriction in Turkey came into effect with the BED } \\
\text { dated } 15 \text { February } 2003\end{array}$ \\
\hline $\begin{array}{l}\text { Establishment of infection control } \\
\text { committees }\end{array}$ & 2003 & $\begin{array}{l}\text { Establishing infection control committees to help prevent the spread of multidrug- } \\
\text { resistant microorganisms, facilitate antibiotic management, and placing authority for } \\
\text { the use of broad-spectrum antibiotics with infectious diseases specialists (e.g., the } \\
\text { regulation passed in Turkey in 2003) are important and necessary steps }\end{array}$ \\
\hline $\begin{array}{l}\text { Notification of Communicable } \\
\text { Diseases and the Reporting System: } \\
\text { Standard Diagnosis, Surveillance, } \\
\text { and Laboratory Guidance }\end{array}$ & 2004 & $\begin{array}{l}\text { In 2004, the "Notification of Communicable Diseases and the Reporting System: } \\
\text { Standard Diagnosis, Surveillance, and Laboratory Guide - 2004" was published together } \\
\text { with a circular }\end{array}$ \\
\hline $\begin{array}{l}\text { Infection Control Regulation for } \\
\text { Inpatient Treatment Institutions }\end{array}$ & 11.08.2005 & $\begin{array}{l}\text { The "Infection Control Regulation for Inpatient Treatment Centers" (Official Gazette, } \\
\text { 11/08/2005/25903) was issued and came into effect with the "Regulation on the } \\
\text { Amendment of the Regulation on the Operation of Inpatient Treatment Institutions" } \\
\text { (Official Gazette, 05/05/2005/25806). Thus, the duties, authority, and responsibilities of } \\
\text { the infection control committee, infection control team, infection control physician, } \\
\text { and infection control nurse were defined in a clear and comprehensive manner }\end{array}$ \\
\hline RDU Workshop & 2006 & The RDU in pharmacology trainings were initiated in the year 2006 with this workshop \\
\hline MEDULA system & 2007 & $\begin{array}{l}\text { The "MEDULA" software was developed in the social security institution and use of the } \\
\text { system became mandatory }\end{array}$ \\
\hline Branch Office of RDU & 12.10 .2010 & Efforts to ensure RDU were increased \\
\hline Prescription Evaluation Project & 26.10 .2010 & The rational use of drugs was promoted \\
\hline Establishment of the TMMDA & 02.11 .2011 & $\begin{array}{l}\text { The TMMDA was established with the "Legislative Decree on the Organization and } \\
\text { Duties of the Ministry of Health and its Affiliates" numbered 663, published in Official } \\
\text { Gazette No. } 28103\end{array}$ \\
\hline RDU national action plan & 2014 & RDU national action plan 2014-2017 (6 headings/20 strategic goals/99 activities). \\
\hline $\begin{array}{l}\text { RDU, Drug Provision Management } \\
\text { and Promotion Office }\end{array}$ & March 2012 & $\begin{array}{l}\text { The RDU, Drug Provision Management and Promotion Office was established within the } \\
\text { TMMDA }\end{array}$ \\
\hline Electronic prescription & January 2013 & $\begin{array}{l}\text { Monitoring usage } \\
\text { Transition to the e-prescription practice in all health institutions }\end{array}$ \\
\hline
\end{tabular}


Table 15. Continued

\begin{tabular}{l|l|l}
\hline Intervention & Date & Comment \\
\hline $\begin{array}{l}\text { Monthly information system for } \\
\text { family physicians }\end{array}$ & November & Facilitated utilization monitoring within the framework of RDU \\
\hline $\begin{array}{l}\text { Prohibition of the use of antibiotics } \\
\text { without a prescription }\end{array}$ & December & $\begin{array}{l}\text { The sale of antibiotics without a prescription was prohibited in Article 24 of the Law on } \\
\text { Pharmacists and Pharmacies No. 6197. }\end{array}$ \\
\hline Office of RDU & 2014 & \\
\hline
\end{tabular}

RDU: Rational drug use, TMMDA: Turkish Medicines and Medical Devices Agency, BED: Budget Execution Directive

\section{Conclusion}

Today, while we debate whether the age of antibiotics has come to an end, ASP and infection control measures are of evergrowing importance. Practices and policies that will promote antibiotic stewardship and the culture of stewardship in health services are needed in Turkey. Government ministries, nongovernmental organizations, the press, and universities must cooperate on this issue. Better planned and more comprehensive AMR and ASP studies are needed in Turkey, as well as globally.

\section{Ethics}

Peer-review: Externally and internally peer-reviewed.

\section{Authorship Contributions}

Surgical and Medical Practices: O.K., A.B., R.Ö., I.Ş., M.A., H.Ş., M.G.G., H.E., G.E.K., A.A., I.G., E.U.G., F.I., S.S.Y., E.Y., H.B., Concept: O.K., A.B., Design: O.K., A.B., Data Collection or Processing: O.K., A.B., R.Ö., I.Ş., M.A., H.Ş., M.G.G., H.E., G.E.K., A.A., I.G., E.U.G., F.I., S.S.Y., E.Y., H.B., Analysis or Interpretation: O.K., A.B., Literature Search: O.K., A.B., R.Ö., E.Y., H.B., Writing: O.K., A.B., R.Ö., I.Ş., M.A., H.Ş., M.G.G., H.E., G.E.K., A.A., I.G., E.U.G., F.I., S.S.Y., E.Y., H.B.

Conflict of Interest: No conflict of interest was declared by the authors.

Financial Disclosure: The authors declared that this study received no financial support.

\section{References}

1. Antimicrobial resistance: global report on surveillance 2014. Last accessed date: 2018 Mar 14. Available from: https://www.who.int/drugresistance/ documents/surveillancereport/en/

2. Kahn LH. Antimicrobial resistance: a One Health perspective. Trans R Soc Trop Med Hyg. 2017;111:255-60.

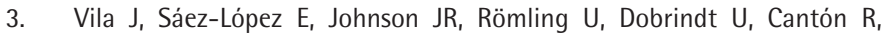
Giske CG, Naas T, Carattoli A, Martínez-Medina M, Bosch J, Retamar P, Rodriguez-Baño J, Baquero F, Soto SM. Escherichia coli: an old friend with new tidings. FEMS Microbiol Rev. 2016;40:437-63.

4. Metan G, Akova M. Reducing the impact of carbapenem-resistant Enterobacteriaceae on vulnerable patient groups: what can be done? Curr Opin Infect Dis. 2016;29:555-60.

5. Vardakas KZ, Mavroudis AD, Georgiou M, Falagas ME. Intravenous colistin combination antimicrobial treatment vs. monotherapy: a systematic review and meta-analysis. Int J Antimicrob Agents. 2018;51:535-47.
6. Cunha BA, Baron J, Cunha CB. Once daily high dose tigecycline pharmacokinetic/pharmacodynamic based dosing for optimal clinical effectiveness: dosing matters, revisited. Expert Rev Anti Infect Ther. 2017;15:257-67.

7. Doi Y, Bonomo RA, Hooper DC, Kaye KS, Johnson JR, Clancy CJ, Thaden JT, Stryjewski ME, van Duin D, Gram-Negative Committee of the Antibacterial Resistance Leadership Group. Gram-Negative Bacterial Infections: Research Priorities, Accomplishments, and Future Directions of the Antibacterial Resistance Leadership Group. Clin Infect Dis. 2017;64(Suppl 1):30-5.

8. Humphreys H, Becker K, Dohmen PM, Petrosillo N, Spencer M, van Rijen M, Wechsler-Fördös A, Pujol M, Dubouix A, Garau J. Staphylococcus aureus and surgical site infections: benefits of screening and decolonization before surgery. J Hosp Infect. 2016;94:295-304.

9. Humphreys H. Staphylococcus aureus: The enduring pathogen in surgery Surgeon. 2012;10:357-60.

10. Walker CLF, Rudan I, Liu L, Nair H, Theodoratou E, Bhutta ZA, O'Brien $\mathrm{KL}$, Campbell H, Black RE. Global burden of childhood pneumonia and diarrhoea. Lancet. 2013;381:1405-16.

11. Kim YK, LaFon D, Nahm MH. Indirect Effects of Pneumococcal Conjugate Vaccines in National Immunization Programs for Children on Adult Pneumococcal Disease. Infect Chemother. 2016;48:257-66.

12. Majowicz SE, Musto J, Scallan E, Angulo FJ, Kirk M, O'Brien SJ, Jones TF, Fazil A, Hoekstra RM; International Collaboration on Enteric Disease "Burden of Illness" Studies. The global burden of nontyphoidal Salmonella gastroenteritis. Clin Infect Dis. 2010;50:882-9.

13. Healthcare-Associated Infection Data Reports. Centers for Disease Control and Prevention 2018. Last accessed date: 2018 Mar 14. Available from: https://www.cdc.gov/hai/surveillance/data-reports/index.html

14. O'Brien TF, Clark A, Peters $R$, Stelling J. Why surveillance of antimicrobial resistance needs to be automated and comprehensive. J Glob Antimicrob Resist. 2018;17:8-15.

15. World Health Organization (WHO). Global action plan on antimicrobial resistance. Last accessed date: 2018 Feb 14. Available from: http://apps. who.int/iris/bitstream/10665/193736/1/9789241509763_eng.pdf

16. Akbaş E, Çöplü N, Şimşek H, Esen B, Sezgin B. Laboratory Evaluation of susceptibility tests for National Antimicrobial Resistance Surveillance System (NAMRSS) in Turkey. Turk Hij Den Biyol Derg. 2018;75:1-12.

17. Simsek H. Ulusal Antimikrobiyal Direnç Sürveyans Sistemi (UAMDSS) Last accessed date: 2018 Mart 14. Available from: http://ekmud.org.tr/sunum/ indir/557-antimikrobiyal-dirence-global-bakis-ve-turkiye

18. Halk Sağlığı Genel Müdürlüğü (HSGM). Ulusal Antimikrobiyal Direnç Sürveyans Sistemi. Last accessed date: 2018 Mart 14. Available from: https://hsgm.saglik.gov.tr/tr/uamdss

19. World Health Organization (WHO). Central Asian and Eastern European Surveillance of Antimicrobial Resistance. Annual report 2016. Last accessed date: 2018 Sep 15. Available from: http://www. euro.who.int/_data/assets/pdf_file/0009/323568/CAESAR-Annualreport-2016.pdf 
20. European Centre for Disease Prevention and Control (ECDC). Surveillance of antimicrobial resistance in Europe 2016. Last accessed date: $2018 \mathrm{Feb}$ 14. Available from: https://ecdc.europa.eu/sites/portal/files/documents/ AMR\%202016_Final-with-cover-for-web-2017.pdf

21. Jim O'Neill. Antimicrobial Resistance: Tackling a crisis for the health and wealth of nations. Last accessed date: 2018 Feb 15. Available from: https://amr-review.org/sites/default/files/AMR\%20Review\%20Paper\%20 -\%20Tackling\%20a\%20crisis\%20for\%20the \%20health\%20and\%20 wealth\%20of\%20nations_1.pdf

22. World Health Organization (WHO). Global action plan on antimicrobial resistance. Last accessed date: 2018 Feb 15. Available from: http://www. who.int/antimicrobial-resistance/global-action-plan/en/

23. Robertson J, Iwamoto K, Hoxha I, Lilit Ghazaryan, Abilova V, Cvijanovic A, Pyshnik H, Darakhvelidze M, Makalkina L, Jakupi A, Dzhakubekova A, Carp A, Cizmovic L, Rachina S, Radonjic V, Yusufi S, Aksoy M, Ibragimova M, Godman B, Kluge H, Bak Pedersen H, WHO Europe AMC Network. Antimicrobial Medicines Consumption in Eastern Europe and Central Asia - An Updated Cross-National Study and Assessment of Quantitative Metrics for Policy Action. Front Pharmacol. 2018;9:1156.

24. Rogers Van Katwyk S, Grimshaw JM, Mendelson M, Taljaard M, Hoffman SJ. Government policy interventions to reduce human antimicrobial use: protocol for a systematic review and meta-analysis. Syst Rev. 2017;6:256.

25. Bassetti M, Di Biagio A, Rebesco B, Amalfitano ME, Topal J, Bassetti D. The effect of formulary restriction in the use of antibiotics in an Italian hospital. Eur J Clin Pharmacol. 2001;57:529-34.

26. Kurt H, Karabay O, Birengel S, Memikoglu O, Yılmaz Bozkurt G, Yalçı A. Effects of legal antibiotic restrictions on consumption of broadspectrum beta-lactam antibiotics, glycopeptides and amphotericin B. Chemotherapy. 2010;56:359-63.

27. Aykan ŞB, Çiftci IH. [Changes in antibiotic resistance of Pseudomonas aeruginosa isolates over the past 11 years in Turkey: a meta-analysis]. Mikrobiyol Bul. 2015 Jul;49(3):352-65.

28. Çelikbilek N, Gözalan A, Özdem B, Kırca F, Açıkgöz ZC. Extended-Spectrum Beta-Lactamase Production by Enterobacteriaceae Isolates From Urine Cultures of Outpatients: Results of a 7-Year Follow-Up. Mikrobiyol Bul. 2015;49:259-65.

29. Yağar F, Soysal A. Akılcı ilaç kullanımı ile ilgili hastane bazında yapılan çalışmaların asistan hekimler üzerindeki etkisinin değerlendirilmesi. International Journal of Management Economics and Business. 2018;14:81-96.

30. Dyar OJ, Huttner B, Schouten J, Pulcini C, ESCMID Study Group for Antimicrobial stewardshiP (ESGAP). What is antimicrobial stewardship? Clin Microbiol Infect. 2017;23:793-8.

31. Fishman N. Antimicrobial stewardship. Am J Infect Control. 2006;34(5 Suppl 1):55-63.

32. Parker SK, Hurst AL, Thurm C, Millard M, Jenkins TC, Child J, Dugan C. Anti-infective Acquisition Costs for a Stewardship Program: Getting to the Bottom Line. Clin Infect Dis. 2017;65:1632-7.

33. Aykan SB, Çiftci IH. Antibiotic Resistance Patterns of Escherichia coli Strains Isolated from Urine Cultures in Turkey: A Meta-Analysis. Mikrobiyol Bul. 2013;47:603-18.

34. World Health Organization (WHO). WHO International Working Group for Drug Statistics Methodology, WHO. WHO Collaborating Center for Drug Statistics Methodology. WHO Collaborating Center for Drug Utilization Research and Clinical Pharmacological Services. Introduction to Drug Utilization Research;2003. Last accessed date: 20 March 2019. Last available from: http://apps.who.int/medicinedocs/pdf/s4876e/ s4876e.pdf

35. European Centre for Disease Prevention and Control (ECDC). Consumption of Antibacterials for systemic use (ATC group J01) in the community (primary care sector) in Europe, reporting year 2017. Last accessed date:
2018 Mar 16. Available from: http://ecdc.europa.eu/en/antimicrobialconsumption/database/rates-country

36. T.C. Sağlık Bakanlığı. Türkiye Akılı İlaç Kullanımı Bülteni;2017. Last accessed date: 2018 Sep 13. Available from: http://www.akilciilac.gov.tr/ wp-content/uploads/2017/08/aik-agsts-bltn-son.pdf

37. Antimicrobial Medicines Consumption (AMC) Network. AMC data 20112014 (2017). Last accessed date: 2018 Mar 16. Available from: http:// www.euro.who.int/en/publications/abstracts/antimicrobial-medicinesconsumption-amc-network.-amc-data-20112014-2017

38. Dellit TH, Owens RC, McGowan JE Jr, Gerding DN, Weinstein RA, Burke JP, Huskins WC, Paterson DL, Fishman NO, Carpenter CF, Brennan PJ, Billeter M, Hooton TM; Infectious Diseases Society of America; Society for Healthcare Epidemiology of America. Infectious Diseases Society of America and the Society for Healthcare Epidemiology of America guidelines for developing an institutional program to enhance antimicrobial stewardship. Clin Infect Dis. 2007;44:159-77.

39. Kang Cl, Kim SH, Park WB, Lee KD, Kim HB, Kim EC, Oh MD, Choe KW. Bloodstream infections caused by antibiotic-resistant gram-negative bacilli: risk factors for mortality and impact of inappropriate initial antimicrobial therapy on outcome. Antimicrob Agents Chemother. 2005;49:760-6.

40. Battle SE, Bookstaver PB, Justo JA, Kohn J, Albrecht H, Al-Hasan MN Association between inappropriate empirical antimicrobial therapy and hospital length of stay in Gram-negative bloodstream infections: stratification by prognosis. J Antimicrob Chemother. 2017;72:299-304.

41. Girometti N, Lewis RE, Giannella M, Ambretti S, Bartoletti M, Tedeschi S, Tumietto F, Cristini F, Trapani F, Gaibani P, Viale P. Klebsiella pneumoniae bloodstream infection: epidemiology and impact of inappropriate empirical therapy. Medicine (Baltimore). 2014;93:298-309.

42. Zilberberg MD, Shorr AF, Micek ST, Vazquez-Guillamet C, Kollef MH. Multidrug resistance, inappropriate initial antibiotic therapy and mortality in Gram-negative severe sepsis and septic shock: a retrospective cohort study. Crit Care. 2014;18:596.

43. Li R, Lu L, Lin Y, Wang M, Liu X. Efficacy and Safety of Metronidazole Monotherapy versus Vancomycin Monotherapy or Combination Therapy in Patients with Clostridium difficile Infection: A Systematic Review and Meta-Analysis. PLoS One. 2015;10:e0137252.

44. Bowers DR, Liew YX, Lye DC, Kwa AL, Hsu LY, Tam VH. Outcomes of appropriate empiric combination versus monotherapy for Pseudomonas aeruginosa bacteremia. Antimicrob Agents Chemother. 2013;57:1270-4.

45. Berkowitz NM, Spaeder MC, DeBiasi RL, Campos J, Singh N. Empiric Monotherapy Versus Combination Therapy for Enterobacteriaceae Bacteremia in Children. Pediatr Infect Dis J. 2015;34:1203-6.

46. Kömür $S$, Ulu AC, Kurtaran $B$, Türkoğlu BÖ, İnal $A S$, Kuşçu $F$, Belgin $B$, Kılıç F, Çiçekdemir HY, Bozkurt S, Gürel D, Aksu SZ, Taşova Y. Bir Günlük Nokta Prevalans ile Bakış: Cerrahi Profilaksi Uygun mu? Mustafa Kemal Üniv Tıp Derg. 2016;7:11-5. Last accessed date: 2018 Sep 14. Available from: http://dergipark.gov.tr/download/article-file/226492

47. Karabay 0. Rights and the Wrongs in Antibiotic Usage. ANKEM Derg. 2013;27(Suppl 2):165-7.

48. Zajmi D, Berisha M, Begolli I, Hoxha R, Mehmeti R, Mulliqi-Osmani G, Kurti A, Loku A, Raka L. Public knowledge, attitudes and practices regarding antibiotic use in Kosovo. Pharm Pract (Granada). 2017;15:827.

49. Huang TY, Hung CH, Lai $\sqcup$, Chuang HJ, Wang CC, Lin PT, Hsu WH. Implementation and outcomes of hospital-wide computerized antimicrobial approval system and on-the-spot education in a traumatic intensive care unit in Taiwan. J Microbiol Immunol Infect. 2018;51:672-80.

50. Wang HY, Chiu CH, Huang CT, Cheng CW, Lin YJ, Hsu YJ, Chen CH, Deng ST, Leu HS. Blood culture-guided de-escalation of empirical antimicrobial regimen for critical patients in an online antimicrobial stewardship programme. Int J Antimicrob Agents. 2014;44:520-7. 
51. Clavenna A, Bonati M. Differences in antibiotic prescribing in paediatric outpatients. Arch Dis Child. 2011;96:590-5.

52. Schwartz RH, Freij BJ, Ziai M, Sheridan MJ. Antimicrobial prescribing for acute purulent rhinitis in children: a survey of pediatricians and family practitioners. Pediatr Infect Dis J. 1997;16:185-90.

53. Butler CC, Rollnick S, Pill R, Maggs-Rapport F, Stott N. Understanding the culture of prescribing: qualitative study of general practitioners' and patients' perceptions of antibiotics for sore throats. BMJ. 1998;317:637-42.

54. Paluck $E$, Katzenstein D, Frankish CJ, Herbert CP, Milner R, Speert D, Chambers K. Prescribing practices and attitudes toward giving children antibiotics. Can Fam Physician. 2001;47:521-7.

55. Abu Hammour K, Farha RA, Alsous M, Rizik M, Hammour WA. Evaluation of risk factors affecting parental knowledge and attitude toward antibiotic use in children with upper respiratory tract infections. Eur J Integr Med. 2018;17:107-11.

56. Jensen JN, Bjerrum L, Boel J, Jarløv JO, Arpi M. Parents' socioeconomic factors related to high antibiotic prescribing in primary healthcare among children aged 0-6 years in the Capital Region of Denmark. Scand J Prim Healthcare. 2016;34:274-81.

57. Malo-Fumanal S, Rabanaque-Hernández MJ, Feja-Solana C, LallanaAlvarez MJ, Armesto-Gómez J, Bjerrum L. Differences in outpatient antibiotic use between a Spanish region and a Nordic country. Enferm Infecc Microbiol Clin. 2014;32:412-7.

58. Macfarlane J, Prewett J, Rose D, Gard P, Cunningham R, Saikku P, Euden $S$, Myint S. Prospective case-control study of role of infection in patients who reconsult after initial antibiotic treatment for lower respiratory tract infection in primary care. BMJ. 1997;315:1206-10.

59. Whaley LE, Businger AC, Dempsey PP, Linder JA. Visit complexity, diagnostic uncertainty, and antibiotic prescribing for acute cough in primary care: a retrospective study. BMC Fam Pract. 2013;14:120.

60. Chaw PS, Maria Schlinkmann MKM, Raupach-Rosin H, Karch A, Pletz MW, Huebner J, Mikolajczyk R. Knowledge, attitude and practice of Gambian health practitioners towards antibiotic prescribing and microbiological testing: a cross-sectional survey. Trans R Soc Trop Med Hyg. 2017;111:11724.

61. Van Vugt SF, Broekhuizen BD, Lammens C, Zuithoff NP, de Jong PA, Coenen $\mathrm{S}$, leven M, Butler CC, Goossens H, Little P, Verheij TJ; GRACE consortium. Use of serum $C$ reactive protein and procalcitonin concentrations in addition to symptoms and signs to predict pneumonia in patients presenting to primary care with acute cough: diagnostic study. BMJ. 2013;346:2450.

62. Hauge C, Stålsby Lundborg C, Mandaliya J, Marrone G, Sharma M. Up to $89 \%$ of neonates received antibiotics in cross-sectional Indian study including those with no infections and unclear diagnoses. Acta Paediatr. 2017; 106:1674-83.

63. Tuon FF, Gasparetto J, Wollmann LC, Moraes TP. Mobile health application to assist doctors in antibiotic prescription - an approach for antibiotic stewardship. Braz J Infect Dis. 2017;21:660-4.

64. Homedes N, Ugalde A. Mexican Pharmacies and Antibiotic Consumption at the US-Mexico Border. South Med Rev. 2012;5:9-19.

65. Okeke IN, Lamikanra A, Edelman R. Socioeconomic and behavioral factors leading to acquired bacterial resistance to antibiotics in developing countries. Emerg Infect Dis. 1999;5:18-27.

66. Ali MH, Kalima P, Maxwell SR. Failure to implement hospital antimicrobial prescribing guidelines: a comparison of two UK academic centres. J Antimicrob Chemother. 2006;57:959-62.

67. Wong-Beringer A, Nguyen LH, Lee M, Shriner KA, Pallares J. An antimicrobial stewardship program with a focus on reducing fluoroquinolone overuse. Pharmacotherapy. 2009;29:736-43.

68. Ocek Z, Sahin H, Baksi G, Apaydin S. Development of a rational antibiotic usage course for dentists. Eur J Dent Educ. 2008;12:41-7.
69. $0^{\prime}$ Neill J. The review on antimicrobial resistance. Tackling drug-resistant infections globally: Final report and recommendations. May 2016. Last accessed date: 2018 Feb 14. Available from: http://amr-review.org/sites/ default/files/160518_Final\%20paper_with\%20cover.pdf

70. The World Bank. Drug-Resistant Infections: A Threat to Our Economic Future. Last accessed date: 2018 Mar 14. Available from: http://www. worldbank.org/en/topic/health/publication/drug-resistant-infections-athreat-to-our-economic-future

71. Jukes TH. Public health significance of feeding low levels of antibiotics to animals. Adv Appl Microbiol. 1973;16:1-54.

72. Anderson ES. Drug Resistance in Salmonella typhimurium and its Implications. Br Med J. 1968;3:333-9.

73. Choraine P. Antibiotic resistance and prudent use of antibiotics in veterinary medicine. Equine Vet Educ. 2010;12:108-12.

74. Sharma C, Rokana N, Chandra M, Singh BP, Gulhane RD, Gill JPS, Ray P, Puniya AK, Panwar H. Antimicrobial Resistance: Its Surveillance, Impact, and Alternative Management Strategies in Dairy Animals. Front Vet Sci. 2017;4:237.

75. Arias KM. Outbreak Investigation, Prevention, and Control in Healthcare Settings: Critical Issues in Patient Safety. Jones \& Bartlett Learning, 2010.

76. Annual Animal Report. Last accessed date: 2018 Mar 14. Available from: https://www.ars.usda.202011\%20Report.pdf

77. So AD, Shah $T A$, Roach $S$, Ling Chee $Y$, Nachman KE. An Integrated Systems Approach is Needed to Ensure the Sustainability of Antibiotic Effectiveness for Both Humans and Animals. J Law Med Ethics. 2015;43(Suppl 3):38-45.

78. Marshall BM, Levy SB. Food Animals and Antimicrobials: Impacts on Human Health. Clin Microbiol Rev. 2011;24:718-33.

79. Coetzee J, Corcoran C, Prentice E, Moodley M, Mendelson M, Poirel L, Nordmann P, Brink AJ. Emergence of plasmid-mediated colistin resistance (MCR-1) among Escherichia coli isolated from South African patients. S Afr Med J. 2016;106:35-6.

80. Harakeh S, Saleh I, Zouhairi O, Baydoun E, Barbour E, Alwan N. Antimicrobial resistance of Listeria monocytogenes isolated from dairybased food products. Sci Total Environ. 2009;407:4022-7.

81. Addis Z, Kebede N, Worku Z, Gezahegn H, Yirsaw A, Kassa T. Prevalence and antimicrobial resistance of Salmonella isolated from lactating cows and in contact humans in dairy farms of Addis Ababa: a cross sectional study. BMC Infect Dis. 2011;11:222.

82. Patel J. Antibiotic Resistance: Understanding and Responding to an Emerging Crisis. Book review: Drlica K, Perlin DS): FT Press, 2010. Emerg Infect Dis. 2011;17:1984.

83. Hoffman SJ, Caleo GM, Daulaire N, Elbe S, Matsoso P, Mossialos E, Rizvi Z, Røttingen JA. Strategies for achieving global collective action on antimicrobial resistance. Bull World Health Organ. 2015;93:867-76.

84. Li XZ, Nikaido H. Efflux-mediated drug resistance in bacteria: an update. Drugs. 2009;69:1555-623. Available from: https://insights.ovid.com/ article/00003495-200969120-00002

85. Centers for Disease Control and Prevention (CDC). Antibiotic Resistance Threats in the United States, 2013. Last accessed date: 2018 Mar 13. Available from: http://www.cdc.gov/drugresistance/pdf/ar-threats-2013-508.pdf

86. Federal Action Plan on Antimicrobial Resistance and Use in Canada Building on The Federal Framework for Action Last accessed date: 2018 Mar 13. Available from: http://healthycanadians.gc.ca/alt/pdf/publications/drugsproducts-medicaments-produits/antibiotic-resistance-antibiotique/ action-plan-daction-eng.pdf

87. Pulcini C. Antibiotic stewardship: update and perspectives. Clin Microbiol Infect. 2017;23:791-2. 
88. Drew RH. Antimicrobial Stewardship Programs: How to Start and Steer a Successful Program. J Manag Care Pharm. 2009;15(2 Suppl):18-23.

89. European Centre for Disease Prevention and Control (ECDC). Strategies and action plans on antimicrobial resistance. Last accessed date: 2018 Mar 14. Available from: http://ecdc.europa.eu/en/publications-data/directoryguidance-prevention-and-control/antimicrobial-resistance-strategies

90. Kullar R, Goff DA. Transformation of antimicrobial stewardship programs through technology and informatics. Infect Dis Clin North Am. 2014;28:291-300.

91. Paskovaty A, Pflomm JM, Myke N, Seo SK. A multidisciplinary approach to antimicrobial stewardship: evolution into the $21^{\text {st }}$ century. Int J Antimicrob Agents. 2005;25:1-10.

92. Ibrahim OM, Polk RE. Antimicrobial use metrics and benchmarking to improve stewardship outcomes: methodology, opportunities, and challenges. Infect Dis Clin North Am. 2014;28:195-214.

93. Leekha $\mathrm{S}$, Terrell CL, Edson RS. General principles of antimicrobial therapy. Mayo Clin Proc. 2011;86:156-67.

94. Huttner B, Harbarth S, Nathwani D; ESCMID Study Group for Antibiotic Policies (ESGAP). Success stories of implementation of antimicrobial stewardship: a narrative review. Clin Microbiol Infect. 2014;20:954-62.

95. Goff DA. Antimicrobial stewardship: bridging the gap between quality care and cost. Curr Opin Infect Dis. 2011;24(Suppl 1):11-20.

96. Levy Hara G, Kanj SS, Pagani L, Abbo L, Endimiani A, Wertheim HF, Amábile-Cuevas C, Tattevin P, Mehtar S, Lopes Cardoso F, Unal S, Gould I. Ten key points for the appropriate use of antibiotics in hospitalised patients: a consensus from the Antimicrobial Stewardship and Resistance Working Groups of the International Society of Chemotherapy. Int J Antimicrob Agents. 2016;48:239-46.

97. Paterson DL. Collateral damage from cephalosporin or quinolone antibiotic therapy. Clin Infect Dis. 2004;38(Suppl 4):341-5.

98. Brunel AS, Guery B. Multidrug resistant (or antimicrobial-resistant) pathogens - alternatives to new antibiotics? Swiss Med Wkly 2017;147:14553.

99. Rhee C. Using Procalcitonin to Guide Antibiotic Therapy. Open Forum Infect Dis. 2016;4:249.

100. Wernli D, Haustein T, Conly J, Harbarth S. Can the application of the international health regulations to antimicrobial resistance events help to preserve antimicrobials? BMC Proc. 2011;5:40.

101. Laxminarayan R, Duse $A$, Wattal $C$, Zaidi AK, Wertheim HF, Sumpradit N, Vlieghe E, Hara GL, Gould IM, Goossens H, Greko C, So AD, Bigdeli M, Tomson G, Woodhouse W, Ombaka E, Peralta AQ, Qamar FN, Mir F, Kariuki S, Bhutta ZA, Coates A, Bergstrom R, Wright GD, Brown ED, Cars 0 . Antibiotic resistance-the need for global solutions. Lancet Infect Dis. 2013;13:1057-98.

102. T.C. Sağlık Bakanlığı. Türkiye Akılcı İlaç Kullanımı Bülteni;2016. Last accessed date: 2018 Feb 14. Available from: http://www.akilciilac.gov.tr/ wp-content/uploads/2015/12/aik-bltn-16.pdf

103. World Health Organization (WHO). WHO Global Strategy for Containment of Antimicrobial Resistance. Last accessed date: 2018 Feb 14. Available from: http://apps.who.int/iris/bitstream/10665/66860/1/WHO_CDS_CSR_ DRS_2001.2.pdf?

104. Dellit TH, Owens RC, McGowan JE Jr, Gerding DN, Weinstein RA, Burke JP, Huskins WC, Paterson DL, Fishman NO, Carpenter CF, Brennan PJ, Billeter M, Hooton TM; Infectious Diseases Society of America; Society for Healthcare Epidemiology of America. Infectious Diseases Society of America and the Society for Healthcare Epidemiology of America guidelines for developing an institutional program to enhance antimicrobial stewardship. Clin Infect Dis. 2007 Jan 15;44:159-77.

105. European Centre for Disease Prevention and Control (ECDC). Data from the ECDC Surveillance Atlas - Antimicrobial resistance. Last accessed date:
2018 Feb 14. Available from: http://www.ecdc.europa.eu/en/healthtopics/ antimicrobial_resistance/database/Pages/database.aspx

106. Sabuncu E, David J, Bernède-Bauduin C, Pépin S, Leroy M, Boëlle P-Y, Watier L, Guillemot D. Significant Reduction of Antibiotic Use in the Community after a Nationwide Campaign in France, 2002-2007. PLoS Med. 2009;6:e1000084.

107. Nathwani D, Sneddon J, Malcolm W, Wiuff C, Patton A, Hurding S, Eastaway A, Seaton RA, Watson E, Gillies E, Davey P, Bennie M; Scottish Antimicrobial Prescribing Group. Scottish Antimicrobial Prescribing Group (SAPG): development and impact of the Scottish National Antimicrobial Stewardship Programme. Int J Antimicrob Agents. 2011;38:16-26.

108. Report on Antimicrobial Use and Resistance in Humans in 2012. Last accessed date: 2018 Feb 14. Available from: https://www.isdscotland. org/Health-Topics/Prescribing-and-Medicines/Publications/2014-0128/2014-01-28-SAPG-2012-Report.pdf

109. Mendelson M, Whitelaw A, Nicol M, Brink A. Wake up South Africa! The antibiotic "horse" has bolted. S Afr Med J. 2012;102:607-8.

110. Molstad S, Cars 0, Struwe J. Strama--a Swedish working model for containment of antibiotic resistance. Euro Surveill. 2008:13;13.

111. Mölstad S, Erntell M, Hanberger $H$, Melander E, Norman C, Skoog G, Lundborg CS, Söderström A, Torell E, Cars O. Sustained reduction of antibiotic use and low bacterial resistance: 10-year follow-up of the Swedish Strama programme. Lancet Infect Dis. 2008;8:125-32.

112. Arda B, Sipahi OR, Yamazhan T, Tasbakan M, Pullukcu H, Tunger A, Buke $C$, Ulusoy S. Short-term effect of antibiotic control policy on the usage patterns and cost of antimicrobials, mortality, nosocomial infection rates and antibacterial resistance. J Infect. 2007;55:41-8.

113. Hoşoğlu $S$, Esen $S$, Ozturk R, Altindis $M$, Ertek $M$, Kaygusuz $S$, Caylan R, Demirdag K, Sencan I, Ertem GT, Aslan S, Bosnak V, Aygun P, Erol $S$, Celen MK. The effect of a restriction policy on the antimicrobial consumption in Turkey: a country-wide study. Eur J Clin Pharmacol. 2005;61:727-31.

114. Ozkurt Z, Erol S, Kadanali A, Ertek M, Ozden K, Tasyaran MA. Changes in antibiotic use, cost and consumption after an antibiotic restriction policy applied by infectious disease specialists. Jpn J Infect Dis. 2005;58:338-43.

115. Kollef $\mathrm{MH}$. Is there a role for antibiotic cycling in the intensive care unit? Crit Care Med. 2001;29(4 Suppl):135-42.

116. Warren DK, Hill HA, Merz LR, Kollef MH, Hayden MK, Fraser VJ, Fridkin SK. Cycling empirical antimicrobial agents to prevent emergence of antimicrobial-resistant Gram-negative bacteria among intensive care unit patients. Crit Care Med. 2004;32:2450-6.

117. Puzniak LA, Mayfield J, Leet T, Kollef M, Mundy LM. Acquisition of Vancomycin-Resistant Enterococci during Scheduled Antimicrobial Rotation in an Intensive Care Unit. Clin Infect Dis. 2001;33:151-7.

118. Cunha BA. Antibiotic Essentials 2009. 8th ed. Jones \& Bartlett Publishers, 2010.

119. van Duijn PJ, Verbrugghe $W$, Jorens $P G$, Spöhr $F$, Schedler $D$, Deja $M$, Rothbart A, Annane D, Lawrence C, Nguyen Van JC, Misset B, Jereb M, Seme K, Šifrer F, Tomiç V, Estevez F, Carneiro J, Harbarth S, Eijkemans MJC, Bonten M; SATURN consortium. The effects of antibiotic cycling and mixing on antibiotic resistance in intensive care units: a clusterrandomised crossover trial. Lancet Infect Dis. 2018;18:401-9.

120. Merz LR, Warren DK, Kollef MH, Fridkin SK, Fraser VJ. The impact of an antibiotic cycling program on empirical therapy for Gram-negative infections. Chest. 2006;130:1672-8.

121. Hedrick TL, Schulman AS, McElearney ST, Smith RL, Swenson BR, Evans HL, Truwit JD, Scheld WM, Sawyer RG. Outbreak of resistant Pseudomonas aeruginosa infections during a quarterly cycling antibiotic regimen. Surg Infect (Larchmt). 2008;9:139-52. 
122. Tobin MJ. Critical care medicine in AJRCCM 2001. Am J Respir Crit Care Med. 2002;165:565-83.

123. Tamma $\mathrm{PD}$, Cosgrove $\mathrm{SE}$, Maragakis LL. Combination Therapy for Treatment of Infections with Gram-Negative Bacteria. Clin Microbiol Rev. 2012;25:450-70.

124. McCullers JA. Preventing and treating secondary bacterial infections with antiviral agents. Antivir Ther. 2011;16:123-35.

125. Chamovitz B, Bryant RE, Gilbert DN, Hartstein Al. Prosthetic valve endocarditis caused by Staphylococcus epidermidis. Development of rifampin resistance during vancomycin and rifampin therapy. JAMA. 1985;253:2867-8.

126. Tepekule B, Uecker H, Derungs I, Frenoy A, Bonhoeffer S. Modeling antibiotic treatment in hospitals: A systematic approach shows benefits of combination therapy over cycling, mixing, and mono-drug therapies. PLoS Comput Biol. 2017;13:e1005745.
127. Sabuncu E, David J, Bernède-Bauduin C, Pépin S, Leroy M, Boëlle PY, Watier L, Guillemot D. Significant reduction of antibiotic use in the community after a nationwide campaign in France, 2002-2007. PLoS Med. 2009;6:e1000084.

128. Kardaś-Słoma L, Boëlle P-Y, Opatowski L, Guillemot D, Temime L. Antibiotic Reduction Campaigns Do Not Necessarily Decrease Bacterial Resistance: the Example of Methicillin-Resistant Staphylococcus aureus. Antimicrob Agents Chemother. 2013;57:4410-6.

129. Huttner B, Goossens $H$, Verheij $T$, Harbarth $S$; CHAMP consortium. Characteristics and outcomes of public campaigns aimed at improving the use of antibiotics in outpatients in high-income countries. Lancet Infect Dis. 2010;10:17-31.

130. Kılıç E, Yenilmez F. An evaluation on antibiotic use, antibiotic resistance and trade balance in Turkey and EU countries. ESTÜDAM Halk Sağlığı Dergisi. 2019;4:45-54.

\section{Acknowledgements}

We would like to thank our colleagues whose names and affiliations are listed below for their contributions to this report.

\begin{tabular}{|c|c|c|c|}
\hline Section & Title & Author & Address \\
\hline I & $\begin{array}{l}\text { Current State of Global Antimicrobial } \\
\text { Resistance }\end{array}$ & $\begin{array}{l}\text { Assoc. Prof. Mustafa Gökhan } \\
\text { Gözel }\end{array}$ & $\begin{array}{l}\text { Ankara Ministry of Health Directorate General of } \\
\text { Public Health, Department of Microbiology Reference } \\
\text { Laboratories, Ankara }\end{array}$ \\
\hline II & $\begin{array}{l}\text { The Current State of Antibiotic } \\
\text { Resistance in Major Pathogens in Turkey }\end{array}$ & $\begin{array}{l}\text { Hüsniye Şimşek } \\
\text { Assoc. Prof. Serap Süzük Yıldız }\end{array}$ & $\begin{array}{l}\text { Ankara Ministry of Health Directorate General of } \\
\text { Public Health, Department of Microbiology Reference } \\
\text { Laboratories and National Antimicrobial Resistance } \\
\text { Surveillance Laboratory, Ankara }\end{array}$ \\
\hline III & $\begin{array}{l}\text { What Can We Expect in } 25 \text { Years If } \\
\text { Antibiotic Resistance Continues to } \\
\text { Increase at This Rate? }\end{array}$ & Assoc. Prof. Aliye Baştuğ & $\begin{array}{l}\text { University of Health Sciences, Ankara Numune Health } \\
\text { Training and Research Center, Clinic of Infectious } \\
\text { Diseases and Clinical Microbiology, Ankara }\end{array}$ \\
\hline IV & $\begin{array}{l}\text { National Policies And Practices of Turkey } \\
\text { and Other Countries to Overcome } \\
\text { Antibiotic Resistance }\end{array}$ & Prof. İrfan Şencan & $\begin{array}{l}\text { University of Health Sciences, Dışkapı Yıldırım Beyazıt } \\
\text { Health Application and Research Center, Clinic of } \\
\text { Infectious Diseases and Clinical Microbiology, Ankara }\end{array}$ \\
\hline V & $\begin{array}{l}\text { Data on Antibiotic Consumption in } \\
\text { Turkey }\end{array}$ & $\begin{array}{l}\text { Mesil Aksoy, } \\
\text { Emre Umut Gürpınar, } \\
\text { Fatma İşi }\end{array}$ & $\begin{array}{l}\text { Turkish Medicines and Medical Devices Agency, Rational } \\
\text { Drug Use Unit, Ankara }\end{array}$ \\
\hline $\mathrm{VI}$ & Causes of Inappropriate Antibiotic Use & Prof. Oğuz Karabay & $\begin{array}{l}\text { Sakarya University Faculty of Medicine, Department of } \\
\text { Infectious Diseases and Clinical Microbiology, Sakarya }\end{array}$ \\
\hline VII & $\begin{array}{l}\text { One Health in Antibiotic Resistance: The } \\
\text { Role of Antibiotic Consumption in Food } \\
\text { and Livestock and Necessary Precautions }\end{array}$ & $\begin{array}{l}\text { Prof. Hürrem Bodur, } \\
\text { Prof. Ender Yarsan }\end{array}$ & $\begin{array}{l}\text { University of Health Sciences, Ankara Numune Health } \\
\text { Application and Research Center, Clinic of Infectious } \\
\text { Diseases and Clinical Microbiology, Ankara } \\
\text { Ankara University Faculty of Veterinary Medicine, } \\
\text { Department of Pharmacology and Toxicology, Ankara }\end{array}$ \\
\hline VIII & Antimicrobial Stewardship Programs & Prof. Recep Öztürk & $\begin{array}{l}\text { Medipol University Faculty of Medicine, Department of } \\
\text { Infectious Diseases and Clinical Microbiology, İstanbul }\end{array}$ \\
\hline IX & $\begin{array}{l}\text { Basic Recommendations for the Rational } \\
\text { Use of Antibiotics }\end{array}$ & $\begin{array}{l}\text { Prof. Haluk Erdoğan, } \\
\text { Gülden Eser Karlıdağ }\end{array}$ & $\begin{array}{l}\text { Başkent University Faculty of Medicine, Department of } \\
\text { Infectious Diseases and Clinical Microbiology, Alanya } \\
\text { Elazığ Training and Research Hospital, Clinic of } \\
\text { Infectious Diseases and Clinical Microbiology, Elazığ }\end{array}$ \\
\hline $\mathrm{X}$ & $\begin{array}{l}\text { Stories of Success in Reducing Antibiotic } \\
\text { Resistance }\end{array}$ & Assoc. Prof. Adalet Aypak & $\begin{array}{l}\text { University of Health Sciences, Ankara Numune Health } \\
\text { Training and Research Center, Clinic of Infectious } \\
\text { Diseases and Clinical Microbiology, Ankara }\end{array}$ \\
\hline $\mathrm{XI}$ & $\begin{array}{l}\text { Interventions That are Unsuccessful in } \\
\text { Reducing Antibiotic Resistance, with } \\
\text { Examples }\end{array}$ & Assoc. Prof. İbak Gönen & $\begin{array}{l}\text { Silivri Medical Park Hospital, Clinic of Infectious } \\
\text { Diseases and Clinical Microbiology, İstanbul }\end{array}$ \\
\hline
\end{tabular}

